Supplemental materials for:

\title{
The Development of an Anomalous Heck Reaction: Skeletal Rearrangement of Divinyl and Enyne Carbinols
}

\author{
J. Maina Ndungu, Kimberly K. Larson, and Richmond Sarpong* \\ Center for New Directions in Organic Synthesis, Department of Chemistry, University of \\ California, Berkeley, California 94720
}

\section{Table of contents:}

Materials and Methods

Optimization of Coupling of Bromobenzene and 1,4-Pentadien-3-ol

Representative Procedure for Palladium Coupling of Aryl Halides with Divinyl and Enyne Carbinols

Scope of the 'Halide' Substrate

Determination of Thermodynamic versus Kinetic Control of the Olefin

Synthetic Utility of the Anomalous Heck Reaction

Synthesis of Substrates

References

Selected ${ }^{1} \mathrm{H}$ Spectral Data 
Materials and Methods. Unless stated otherwise, reactions were performed in flamedried glassware sealed with rubber septa under nitrogen atmosphere using dry deoxygenated solvents. Reaction temperatures were controlled by an IKAmag® temperature modulator. Thin layer chromatography was performed using E. Merck silica gel 60 F254 precoated plates $(0.25 \mathrm{~mm})$ and visualized by UV and anisaldehyde stain. Fisher silica gel 240-400 mesh (particle size $0.032-0.063 \mathrm{~mm}$ ) was used for flash chromatography. Photochemical irradiation was performed in septum sealed quartz tubes with a Luzchem ${ }^{\circledR}$ Photochemical reactor. ${ }^{1} \mathrm{H}$ and ${ }^{13} \mathrm{C}$ NMR were recorded on a Bruker DRX500 (at $500 \mathrm{MHz}$ and $125 \mathrm{MHz}$ respectively). Chemical shifts ( $\delta \mathrm{ppm}$ ) are reported relative to $\mathrm{Me}_{4} \mathrm{Si}(\delta=0.0)$ or $\mathrm{CHCl}_{3}\left(\delta=7.26\right.$ for ${ }^{1} \mathrm{H} \mathrm{NMR}$ and $\delta=77.2$ for $\left.{ }^{13} \mathrm{C} \mathrm{NMR}\right)$. Data for ${ }^{1} \mathrm{H}$ NMR are reported as follows: chemical shift $(\delta \mathrm{ppm})$, multiplicity, $(\mathrm{s}=$ singlet, $\mathrm{d}=$ doublet, $\mathrm{t}=$ triplet, $\mathrm{q}=$ quartet, $\mathrm{dd}=$ doublet of doublets, $\mathrm{dt},=$ doublet of triplets, $\mathrm{dq}=$ doublet of quartets, $\mathrm{m}=$ multiplet, $\mathrm{br}=$ broad signal), coupling constant (Hz) and integration. IR spectra were recorded on a Nicolet MAGNA-IR 850 spectrometer and are reported in frequency of absorption $\left(\mathrm{cm}^{-1}\right)$. High resolution mass spectral data were obtained from the University of California, Berkeley Mass Spectral Facility. 
Table S1. Optimization of Coupling of Bromobenzene and 1,4-Pentadien-3-ol.

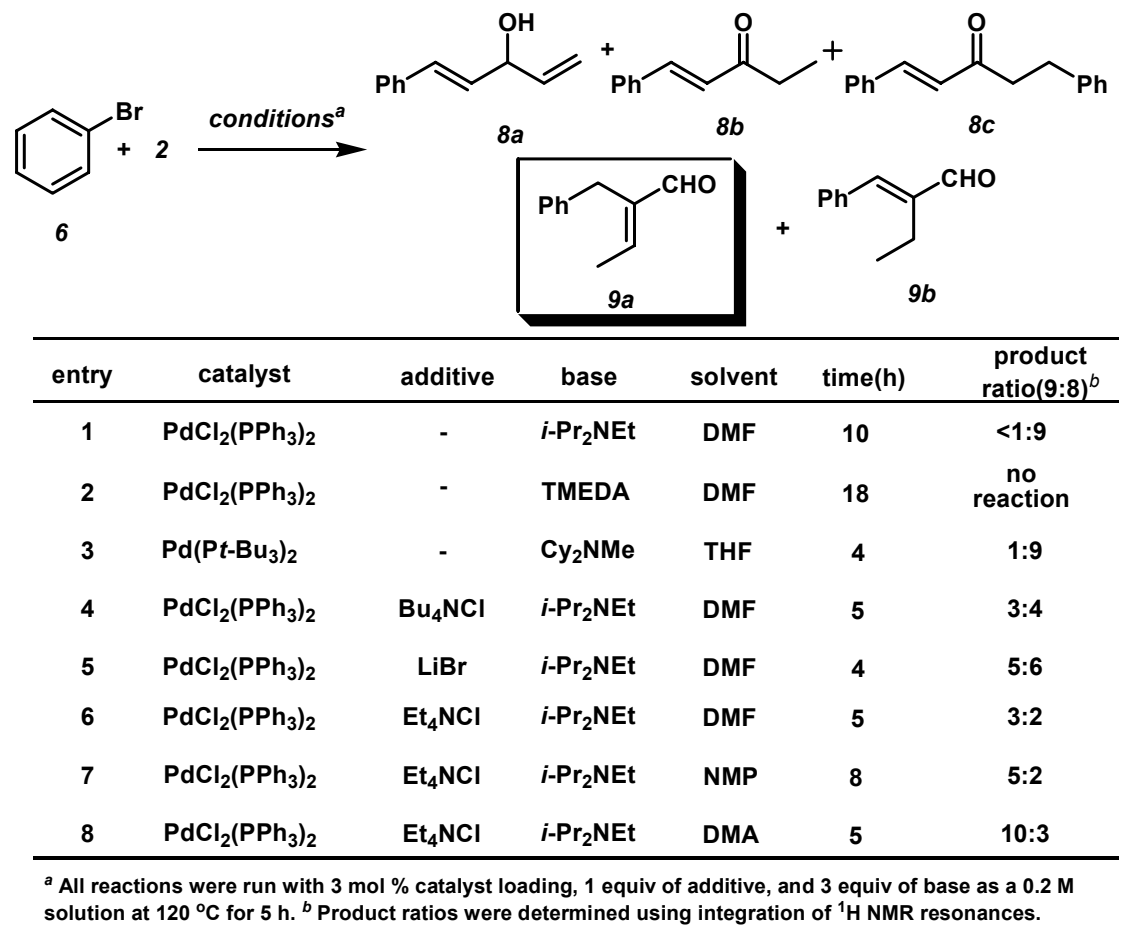

Coupling of bromobenzene with 1,4-pentadien-3-ol in the presence of $\mathrm{PdCl}_{2}\left(\mathrm{PPh}_{3}\right)_{2}(3$ mol \%) and Hünigs base ( 3 equiv) at $80{ }^{\circ} \mathrm{C}$ in DMF led to the formation of a mixture of compounds with the major product as compound $\mathbf{8 c}$ (entry 1, Table S1). Formation of 8ac suggested $\beta$-hydride elimination, leading to standard Heck products, was a more facile pathway. To minimize $\beta$-hydride elimination, three factors (base, catalyst, additives and solvent), were screened. The use of TMEDA (entry 2) or a mixture of TMEDA (2.0 equiv) and Hünigs base (2.0 equiv) resulted in no reaction. $\mathrm{Pd}\left(\mathrm{P} t-\mathrm{Bu}_{3}\right)_{2}$, a catalyst shown to minimize $\beta$-hydride elimination, gave $\mathbf{8 c / 8 b}$ as the major products in addition to trace amounts of 9a.

With regard to additives in the presence of $\mathrm{PdCl}_{2}\left(\mathrm{PPh}_{3}\right)_{2}, \mathrm{LiBr}$ (2 equiv) favored the formation of 8c. Soluble quaternary ammonium chlorides have found use in Heck couplings as they keep the concentration of soluble chloride high, stabilizing and 
activating palladium $(0)$ complexes. ${ }^{1}$ Addition of $\mathrm{Bu}_{4} \mathrm{NCl}$ to the reaction with $\mathrm{DMF}$ as solvent led to a cleaner reaction but formation of $\mathbf{8 c}$ was still favored. $\mathrm{Et}_{4} \mathrm{NCl}$ proved to be the most effective additive leading to the formation of $9 \mathbf{a}$ and $\mathbf{8 c}$ in a ratio of $3: 2$, respectively. Substitution of NMP for DMF favored formation of the desired product and this was improved further by use of DMA as solvent. Our improved reaction conditions worked well with different combinations of aryl halides and divinyl or enyne carbinols. By-product 8c was observed under these conditions only when using bromo- or iodobenzene as the halide substrate but not with other aryl halides. A free hydroxyl group was found to be necessary for the reaction since both benzyl protected 1,4-pentadien-3-ol and methyl protected 3-phenyl-penta-1,4-dien-3-ol resulted in no reaction under our optimized conditions.

Representative procedure for Palladium coupling of aryl halides with divinyl and enyne carbinols (Entry 1, Table $\mathrm{S} 2$ is used as an example). A solution of bromobenzene $(100 \mu \mathrm{L}, 0.95 \mathrm{mmol}), 1,4$-pentadien-3-ol $(180 \mu \mathrm{L}, 1.86 \mathrm{mmol})$, and Hünig's base $(500 \mu \mathrm{L}, 2.87 \mathrm{mmol})$ in DMA $(5.0 \mathrm{~mL})$ was added via syringe to a schlenck tube containing $\mathrm{PdCl}_{2}\left(\mathrm{PPh}_{3}\right)_{2}(20.0 \mathrm{mg}, 0.0285 \mathrm{mmol})$ and tetraethylammonium chloride (160.0 $\mathrm{mg}, 0.96 \mathrm{mmol}$ ). The combined mixture was evacuated briefly (ca. $5 \mathrm{sec}$ ), backfilled with nitrogen $(3 \mathrm{X})$, sealed tightly and inserted in an oil bath preheated to $120^{\circ} \mathrm{C}$. The solution was held at this temperature for $5 \mathrm{~h}$. After cooling to $23{ }^{\circ} \mathrm{C}$, the solution was diluted with ether $(20 \mathrm{~mL})$ and washed with $1 \%$ aqueous $\mathrm{HCl}(2 \times 10 \mathrm{~mL})$. The aqueous layers were combined and extracted with ether $(2 \times 10 \mathrm{~mL})$. The combined ethereal phase was washed with $1 \%$ aqueous $\mathrm{HCl}(10 \mathrm{~mL})$ and brine $(10 \mathrm{~mL})$, dried over $\mathrm{MgSO}_{4}$ and concentrated in vacuo to yield an amber oily product. The crude product was 
Table S2. Scope of the Carbinol Component.

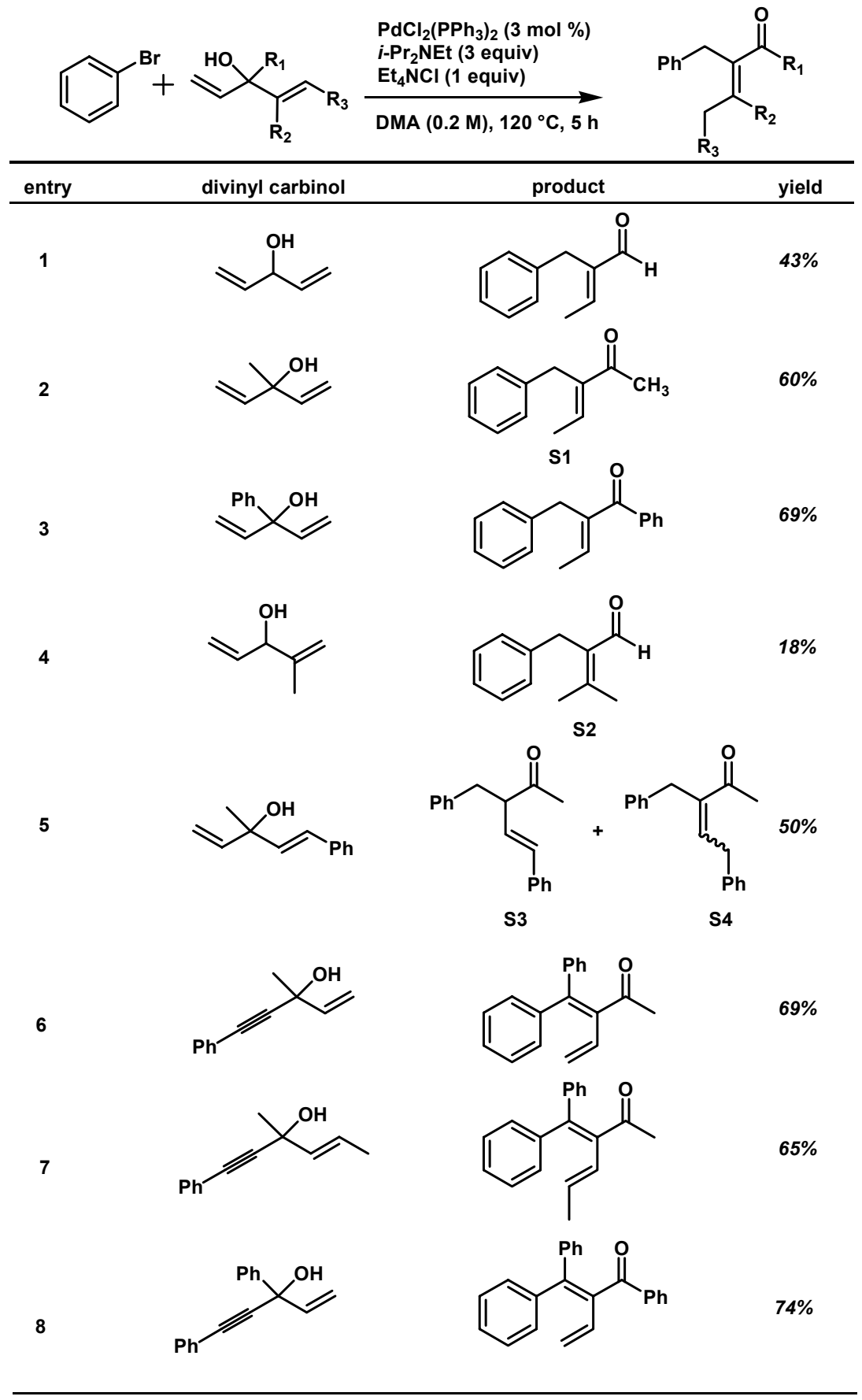

purified by flash chromatography (6:1 hexanes:EtOAc) to give $65.0 \mathrm{mg}$ of $\mathbf{8 a}$ as a yellow oil in $43 \%$ yield. $\mathrm{R}_{\mathrm{F}} 0.50$ (2:1 hexanes:EtOAc); ${ }^{1} \mathrm{H}$ NMR $\left(500 \mathrm{MHz}, \mathrm{CDCl}_{3}\right) \delta 9.46(\mathrm{~s}$, 1H), 7.26-7.23 (m, 2H), 7.18-7.16 (m, 3H), $6.73(\mathrm{q}, J=7.0 \mathrm{~Hz}, 1 \mathrm{H}), 3.64(\mathrm{~s}, 2 \mathrm{H}), 2.04(\mathrm{~d}$, 
$J=7.0 \mathrm{~Hz}, 3 \mathrm{H}) ;{ }^{13} \mathrm{C}$ NMR $\left(125 \mathrm{MHz}, \mathrm{CDCl}_{3}\right), \delta 194.6,151.1,143.7,139.2,128.6$, 128.5, 126.2, 29.5, 15.4; IR (film) 3061, 3028, 2926, 2817, 2717, 1684, 1642, 1495, 1453, 1179, 1071, 735, $699 \mathrm{~cm}^{-1}$; HRMS $\left(\mathrm{EI}^{+}\right)$calc'd for $\left[\mathrm{C}_{11} \mathrm{H}_{12} \mathrm{O}\right]^{+}: m / z 160.0888$, found 160.0891. $25.0 \mathrm{mg}$ of $7 \mathrm{c}$ was also isolated and all the characterization data corresponded to literature values. ${ }^{2}$

Entry 2. The crude product was purified by flash chromatography (6:1 hexanes:EtOAc) to give $99.0 \mathrm{mg}$ of a clear colorless liquid in $60 \%$ yield. $\mathrm{R}_{\mathrm{F}} 0.44$ (2:1 hexanes:EtOAc); ${ }^{1} \mathrm{H}$ $\operatorname{NMR}\left(500 \mathrm{MHz}, \mathrm{CDCl}_{3}\right) \delta$ 7.26-7.22 (m, 2H), 7.16-7.14 (m, 3H), $6.91(\mathrm{q}, J=7.0 \mathrm{~Hz}$, 1H), $3.69(\mathrm{~s}, 1 \mathrm{H}), 2.31(\mathrm{~s}, 3 \mathrm{H}), 1.94(\mathrm{~d}, J=7.0 \mathrm{~Hz}, 3 \mathrm{H}):{ }^{13} \mathrm{C} \mathrm{NMR}\left(125 \mathrm{MHz}, \mathrm{CDCl}_{3}\right) \delta$ 199.1, 142.2, 140.0, 128.5, 128.4, 126.0, 30.8, 25.9, 15.3; IR (film) 3061, 3028, 2928, 2360, 2342, 1667, 1639, 1494, 1271, $716 \mathrm{~cm}^{-1}$; HRMS $\left(\mathrm{EI}^{+}\right)$calc'd for $\left[\mathrm{C}_{12} \mathrm{H}_{14} \mathrm{O}\right]^{+}: \mathrm{m} / \mathrm{z}$ 174.1000, found 174.1047.

Entry 3. The reaction was run using 1.2 equiv of the alcohol. The crude product was purified by flash chromatography ( $8: 1$ hexanes:EtOAc) to give $139.0 \mathrm{mg}$ of a yellow oil in $69 \%$ yield. $\mathrm{R}_{\mathrm{F}} 0.61\left(2: 1\right.$ hexanes:EtOAc); ${ }^{1} \mathrm{H}$ NMR $\left(500 \mathrm{MHz}, \mathrm{CDCl}_{3}\right) \delta 7.60(\mathrm{~d}, J=$ $7.5 \mathrm{~Hz}, 2 \mathrm{H}), 7.47$ (t, $J=7.5 \mathrm{~Hz}, 2 \mathrm{H}), 7.38$ (t, $J=7.5 \mathrm{~Hz}, 2 \mathrm{H}), 7.27-7.22(\mathrm{~m}, 4 \mathrm{H}), 7.17-$ $7.14(\mathrm{~m}, 1 \mathrm{H}), 6.49$ (q, $J=7.0 \mathrm{~Hz}, 1 \mathrm{H}), 3.88(\mathrm{~s}, 2 \mathrm{H}), 1.95(\mathrm{~d}, J=7.0 \mathrm{~Hz}, 3 \mathrm{H}) ;{ }^{13} \mathrm{C}$ NMR (125 MHz, $\left.\mathrm{CDCl}_{3}\right), \delta 198.3,141.9,141.3,139.8,138.9,131.6,129.4,128.6,128.5$, 128.2, 126.1, 32.1, 15.1; IR (film) 3060, 3027, 2921, 1647, 1598, 1447, 1278, $700 \mathrm{~cm}^{-1}$; HRMS (EI ${ }^{+}$) calc'd for $\left[\mathrm{C}_{17} \mathrm{H}_{16} \mathrm{O}\right]^{+}: \mathrm{m} / \mathrm{z} 236.1201$, found 236.1206 .

Entry 4. Coupling of bromobenzene and 2-methyl-penta-1,4-dien-3-ol. Coupling of bromobenzene and 2-methyl-penta-1,4-dien-3-ol (2.0 equiv) under our optimized conditions led to the formation of the desired product in $18 \%$ yield (Scheme S1). The 
other products that were isolated ( $\mathbf{S 5}$ and $\mathbf{S 6}$, Scheme S1) were formed from $\beta$-hydride and $\beta$ '-hydride elimination. Compound $\mathbf{S 2}$ was fully characterized while data for $\mathbf{S 5}$ and S6 was consistent with literature data. ${ }^{3}$

Scheme S1. Coupling of bromobezene and 2-methyl-penta-1,4-dien-3-ol.

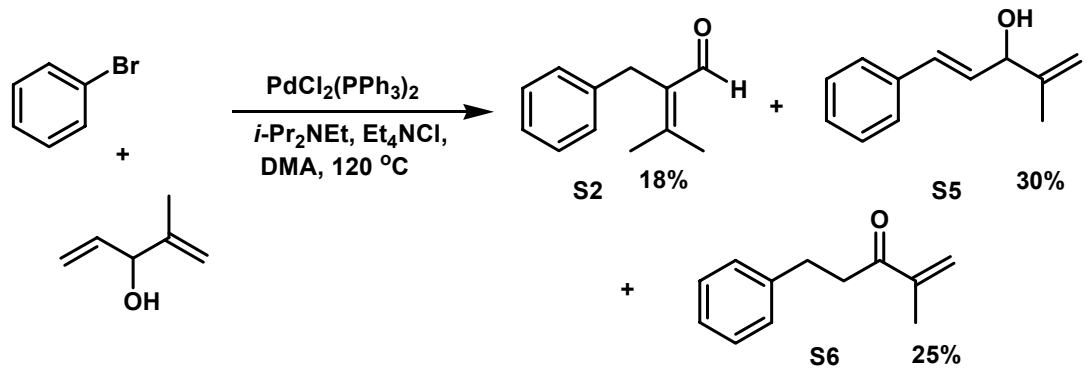

$\mathrm{R}_{\mathrm{F}} 0.6\left(2: 1\right.$ hexanes:EtOAc); ${ }^{1} \mathrm{H}$ NMR $\left(500 \mathrm{MHz}, \mathrm{CDCl}_{3}\right) \delta 10.22(\mathrm{~s}, 1 \mathrm{H}), 7.26-7.22(\mathrm{~m}$, 3H), 7.16-7.12 (m, 2H), 3.67 (s, 2H), $2.25(\mathrm{~s}, 3 \mathrm{H}), 2.0(\mathrm{~s}, 3 \mathrm{H}) ;{ }^{13} \mathrm{C}$ NMR $(125 \mathrm{MHz}$, $\left.\mathrm{CDCl}_{3}\right) \delta 190.8,156.9,140.2,136.1,128.5,128.3,125.9,31.0,24.1,19.7 ;$ IR (film) 3062, 3028, 2934, 1717, 1495, 1454, 1375, 1291, 1152, 1081, 727, $699 \mathrm{~cm}^{-1}$; HRMS $\left(\mathrm{EI}^{+}\right)$calc'd for $\left[\mathrm{C}_{12} \mathrm{H}_{14} \mathrm{O}\right]^{+}: \mathrm{m} / z$ 174.1045, found 174.1046.

Entry 5. Coupling of bromobenzene with 3-methyl-1-phenylpenta-1,4-dien-3-ol. The reaction was run using 1.2 equiv of the alcohol (Scheme S2). The crude product was purified by flash chromatography (10:1 hexanes:EtOAc) to give a mixture of $\mathbf{S 3}$ and $\mathbf{S 4}$ in $50 \%$ yield. A pure sample of $\mathbf{S 3}$ was obtained as a yellow oil and fully characterized. ${ }^{1} \mathrm{H}$ NMR $\left(500 \mathrm{MHz}, \mathrm{CDCl}_{3}\right) \delta 7.33-7.15(\mathrm{~m}, 10 \mathrm{H}), 6.43(\mathrm{~d}, J=16.0 \mathrm{~Hz}, 1 \mathrm{H}), 6.15-$ $6.10(\mathrm{dd}, J=9.0,16.0 \mathrm{~Hz}, 1 \mathrm{H}), 3.58$ (app. q, $J=7.0,9.0 \mathrm{~Hz}, 1 \mathrm{H}), 3.19-3.15(\mathrm{dd}, J=$ 7.0, $14.0 \mathrm{~Hz}, 1 \mathrm{H}), 2.86-2.82(\mathrm{dd}, J=7.0,14.0 \mathrm{~Hz}, 1 \mathrm{H}), 2.12(\mathrm{~s}, 3 \mathrm{H}) ;{ }^{13} \mathrm{C}$ NMR $(125$ $\left.\mathrm{MHz}, \mathrm{CDCl}_{3}\right) \delta 208.4,139.1,136.6,133.4,129.0,128.6,128.4,127.7,127.0,126.3$, 59.0, 37.6, 37.6, 29.6; IR (film) 3083, 3060, 2924, 1713, 1670, 1495, 1453, 1354, 1158, 
1073, 969, 746, $697 \mathrm{~cm}^{-1}$; HRMS $\left(\mathrm{EI}^{+}\right)$calc'd for $\left[\mathrm{C}_{12} \mathrm{H}_{14} \mathrm{O}\right]^{+}: \mathrm{m} / z$ 250.1358, found 250.1361 .

Scheme S2.

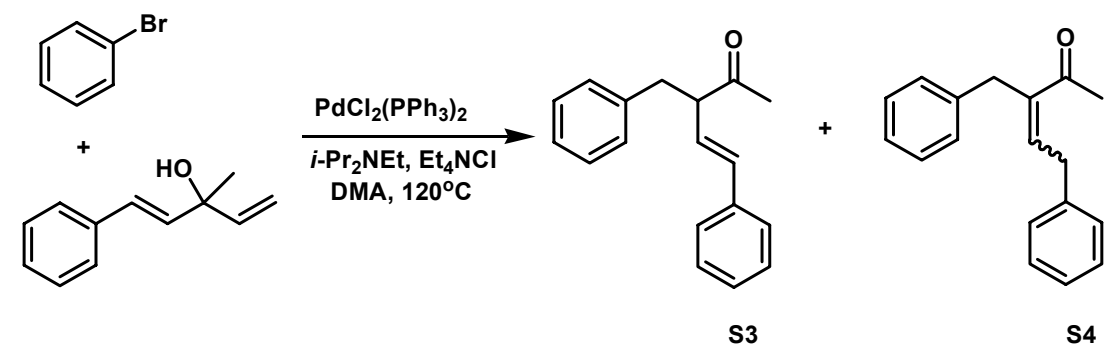

Entry 6. The reaction was run using 1.2 equiv of the alcohol. The crude product was purified by flash chromatography ( $8: 1$ hexanes:EtOAc) to give $162.0 \mathrm{mg}$ of a yellow oil in $69 \%$ yield. $\mathrm{R}_{\mathrm{F}} 0.58$ (2:1 hexanes:EtOAc); ${ }^{1} \mathrm{H} \mathrm{NMR}\left(500 \mathrm{MHz}, \mathrm{CDCl}_{3}\right) \delta$ 7.38-7.15 (m, $10 \mathrm{H}), 6.45(\mathrm{dd}, J=11.0,17.0 \mathrm{~Hz}), 5.23(\mathrm{~s}, 1 \mathrm{H}), 5.20(\mathrm{~d}, J=7.0 \mathrm{~Hz}, 2 \mathrm{H}), 2.01(\mathrm{~s}, 3 \mathrm{H})$; ${ }^{13} \mathrm{C}$ NMR $\left(125 \mathrm{MHz}, \mathrm{CDCl}_{3}\right) \delta 207.3,142.9,141.0,140.0,133.2,130.7,129.9,128.6$, 128.5, 128.3, 128.2, 117.9, 31.9; IR (film) 3056, 3025, 1692, 1492, 1444, 1352, 1240, 756, 701; HRMS (EI ${ }^{+}$) calc'd for $\left[\mathrm{C}_{18} \mathrm{H}_{16} \mathrm{O}\right]^{+}: \mathrm{m} / \mathrm{z} 248.1201$, found 248.1198 .

Entry 7. The reaction was run using 1.2 equiv of the alcohol. The crude product was purified by flash chromatography (8:1 hexanes:EtOAc) to give $162.0 \mathrm{mg}$ of a yellow oil in $65 \%$ yield. $\mathrm{R}_{\mathrm{F}} 0.69$ (2:1 hexanes:EtOAc); ${ }^{1} \mathrm{H}$ NMR $\left(500 \mathrm{MHz}, \mathrm{CDCl}_{3}\right) \delta$ 7.33-7.29 (m, 6H), 7.20-7.17 (m, 2H), 7.15-7.13 (m, 2H), $5.93(\mathrm{dq}, J=2.0,11.5 \mathrm{~Hz}, 1 \mathrm{H}), 5.66-5.60$ (dq, $J=7.0,11.5 \mathrm{~Hz}, 1 \mathrm{H}), 2.03(\mathrm{~s}, 3 \mathrm{H}), 1.56(\mathrm{dd}, J=1.5,7.0 \mathrm{~Hz}) ;{ }^{13} \mathrm{C} \mathrm{NMR}(125 \mathrm{MHz}$, $\left.\mathrm{CDCl}_{3}\right) \delta 206.8,1461,141.4,140.8,138.8,131.0,130.2,129.2,128.6,128.5,128.3$, 128.28, 127.9, 31.1, 15.9; IR (film) 3055, 3021, 1689, 1492, 1444, 1352, 1224, 1119, $761,700 \mathrm{~cm}^{-1}$; HRMS $\left(\mathrm{EI}^{+}\right)$calc'd for $\left[\mathrm{C}_{19} \mathrm{H}_{18} \mathrm{O}\right]^{+}: \mathrm{m} / z$ 262.1358, found 262.1360 . 
Entry 8. The reaction was run using 1.2 equiv of the alcohol. The crude product was purified by flash chromatography ( $8: 1$ hexanes:EtOAc) to give $220.0 \mathrm{mg}$ of a yellow oil in $66 \%$ yield. $\mathrm{R}_{\mathrm{F}} 0.47$ (4:1 hexanes:EtOAc); ${ }^{1} \mathrm{H}$ NMR $\left(500 \mathrm{MHz}, \mathrm{CDCl}_{3}\right) \delta 7.88$ (app. d, 7.88, $J=7.5 \mathrm{~Hz}, 2 \mathrm{H}), 7.41-7.29(\mathrm{~m}, 8), 7.06-7.03(\mathrm{~m}, 5), 6.69(\mathrm{dd}, J=11.0,17.5 \mathrm{~Hz}$, $1 \mathrm{H}), 5.21(\mathrm{~d}, J=11.0 \mathrm{~Hz}, 1 \mathrm{H}), 5.11(\mathrm{~d}, J=17.5 \mathrm{~Hz}, 1 \mathrm{H}) ;{ }^{13} \mathrm{C} \mathrm{NMR}\left(125 \mathrm{MHz}, \mathrm{CDCl}_{3}\right) \delta$ $199.5,143.9,140.9,140.2,138.0,137.5,134.6,133.2,130.7,130.0,129.4,128.5,128.3$, 128.2, 128.02, 128.0, 188.9; IR (film) 3431, 3057, 1669, 1596, 1445, 1261, 1169, 699 $\mathrm{cm}^{-1}$; HRMS $\left(\mathrm{EI}^{+}\right)$calc'd for $\left[\mathrm{C}_{12} \mathrm{H}_{14} \mathrm{O}\right]^{+}: m / z 310.1358$, found 310.1361. 
Table S3. Scope of the 'Halide' Substrate.

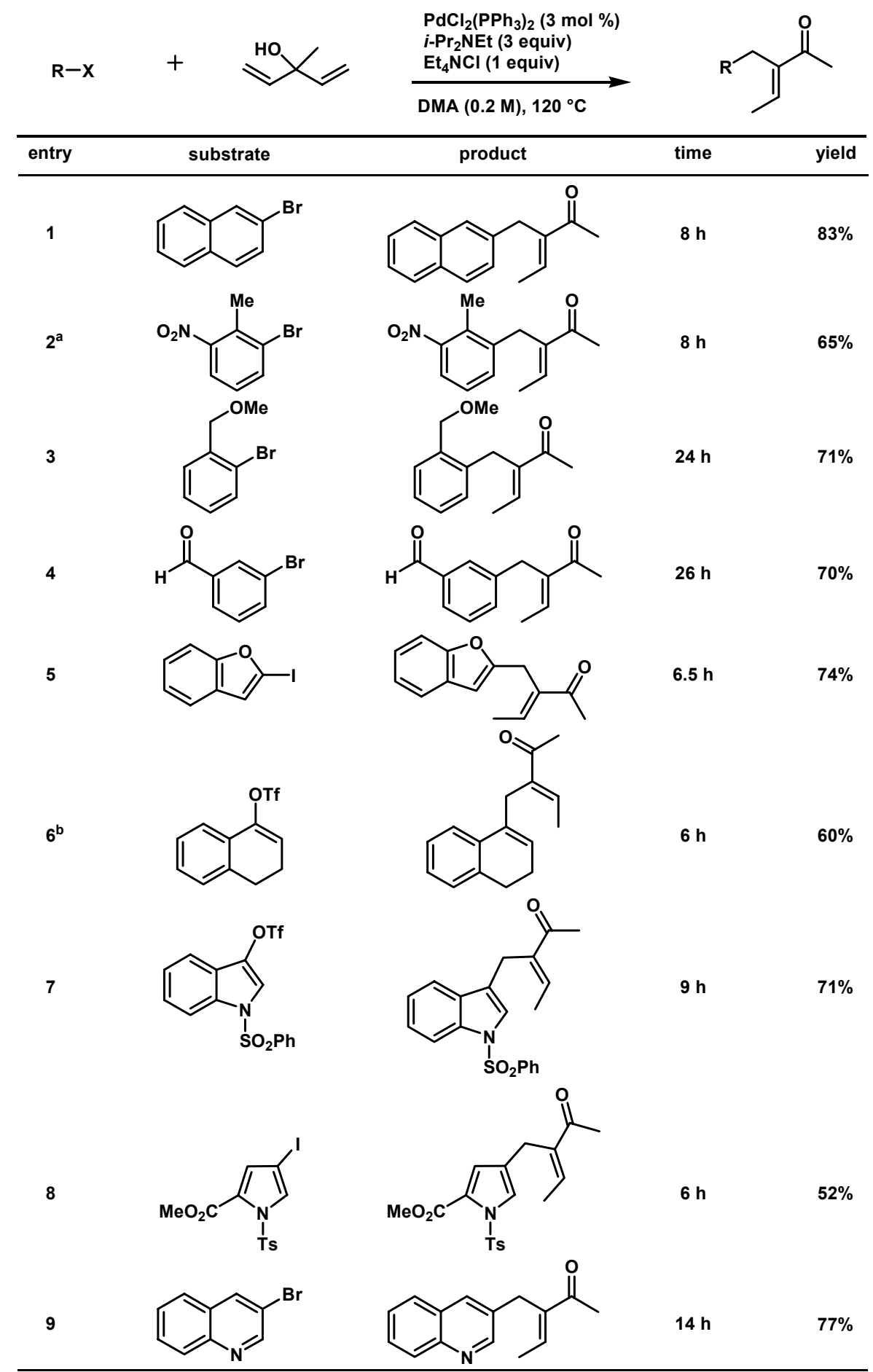

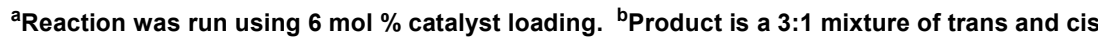
isomers. Major product is shown. 
Entry 1. The reaction was heated at $120^{\circ} \mathrm{C}$ for $8 \mathrm{~h}$. The crude product was purified by flash chromatography (using a gradient from 9:1 to 4:1 hexanes/EtOAc) to afford $177 \mathrm{mg}$ of a yellow oil in $83 \%$ yield. $\mathrm{R}_{\mathrm{F}} 0.47$ (2:1 hexanes/EtOAc); ${ }^{1} \mathrm{H} \mathrm{NMR}\left(500 \mathrm{MHz}, \mathrm{CDCl}_{3}\right)$ $\delta$ 7.78-7.72 (m, 3H), $7.56(\mathrm{~s}, 1 \mathrm{H}), 7.44-7.38(\mathrm{~m}, 2 \mathrm{H}), 7.31(\mathrm{~d}, J=8.5 \mathrm{~Hz}, 1 \mathrm{H}), 6.97(\mathrm{q}, J$ $=7.0 \mathrm{~Hz}, 1 \mathrm{H}), 3.86(\mathrm{~s}, 2 \mathrm{H}), 2.34(\mathrm{~s}, 3 \mathrm{H}), 1.98(\mathrm{~d}, J=7.0 \mathrm{~Hz}, 3 \mathrm{H}) ;{ }^{13} \mathrm{C} \mathrm{NMR}(125 \mathrm{MHz}$, $\left.\mathrm{CDCl}_{3}\right) \delta 199.0,142.1,140.4,137.5,133.7,132.1,128.1,127.7,127.6,127.4,126.4$ 126.0, 125.3, 31.0, 25.9, 15.4; IR (film) 3053, 3015, 1665, 1637, 1387, 1277, 816, 758 $\mathrm{cm}^{-1}$; HRMS $\left(\mathrm{EI}^{+}\right)$calc'd for $\left[\mathrm{C}_{16} \mathrm{H}_{16} \mathrm{O}\right]^{+}: \mathrm{m} / z$ 224.1201, found 224.1203.

Entry 2. The reaction was run for $8 \mathrm{~h}$ at $120{ }^{\circ} \mathrm{C}$ using $6 \mathrm{~mol} \%$ catalyst because the longer reaction time needed for completion of the reaction using $3 \mathrm{~mol} \%$ catalyst led to reduction of the nitro group to the corresponding amine. The crude product was purified by flash chromatography (using a gradient from 9:1 to 4:1 hexanes/EtOAc) to afford 144 mg of a yellow oil in 65\% yield. $\mathrm{R}_{\mathrm{F}} 0.34$ (2:1 hexanes/EtOAc); ${ }^{1} \mathrm{H}$ NMR $(500 \mathrm{MHz}$, $\left.\mathrm{CDCl}_{3}\right) \delta 7.55(\mathrm{~d}, J=8.0 \mathrm{~Hz}, 1 \mathrm{H}), 7.16(\mathrm{t}, J=7.9 \mathrm{~Hz}, 1 \mathrm{H}), 7.09-7.06(\mathrm{~m}, 2 \mathrm{H}), 3.67(\mathrm{~s}$, 2H), $2.46(\mathrm{~s}, 3 \mathrm{H}), 2.37(\mathrm{~s}, 3 \mathrm{H}), 1.87(\mathrm{~d}, J=7.0 \mathrm{~Hz}, 3 \mathrm{H}) ;{ }^{13} \mathrm{C} \mathrm{NMR}\left(125 \mathrm{MHz}, \mathrm{CDCl}_{3}\right) \delta$ 198.7, 151.6, 141.6, 140.8, 140.5, 130.8, 130.4, 126.2, 121.8, 28.6, 25.7, 15.4, 15.0; IR (film) 3048, 1667, 1643, 1525, 1387, 1351, 1282, $734 \mathrm{~cm}^{-1}$; HRMS (EI $\left.{ }^{+}\right)$calc'd for $\left[\mathrm{C}_{13} \mathrm{H}_{15} \mathrm{NO}_{3}\right]^{+}: m / z$ 233.1052, found 233.1053.

Entry 3. The reaction was heated at $120^{\circ} \mathrm{C}$ for $24 \mathrm{~h}$. The crude product was purified by flash chromatography (using a gradient from 9:1 to 4:1 hexanes/EtOAc) to afford $147 \mathrm{mg}$ of a yellow oil in $71 \%$ yield. $\mathrm{R}_{\mathrm{F}} 0.40\left(2: 1\right.$ hexanes/EtOAc); ${ }^{1} \mathrm{H} \mathrm{NMR}\left(500 \mathrm{MHz}, \mathrm{CDCl}_{3}\right)$ $\delta$ 7.32-7.30 (m, 1H), 7.18-7.14 (m, 2H), $7.00(\mathrm{q}, J=7.0 \mathrm{~Hz}, 1 \mathrm{H}), 6.91-6.89(\mathrm{~m}, 1 \mathrm{H}), 4.59$ $(\mathrm{s}, 2 \mathrm{H}), 3.72(\mathrm{~s}, 2 \mathrm{H}), 3.41(\mathrm{~s}, 3 \mathrm{H}), 2.33(\mathrm{~s}, 3 \mathrm{H}), 1.88(\mathrm{~d}, J=7.0 \mathrm{~Hz}, 3 \mathrm{H}) ;{ }^{13} \mathrm{C} \mathrm{NMR}(125$ 
$\left.\mathrm{MHz}, \mathrm{CDCl}_{3}\right) \delta 199.1,141.6,140.6,138.2,135.9,129.1,128.0,127.2,125.9,73.2,58.2$, 27.0, 25.9, 15.2; IR (film) 2983, 1667, 1455, 1387, 1088, $760 \mathrm{~cm}^{-1}$; HRMS $\left(\mathrm{FAB}^{+}\right.$) calc'd for $\left[\mathrm{C}_{14} \mathrm{H}_{19} \mathrm{O}_{2}\right]^{+}: \mathrm{m} / \mathrm{z} 219.1385$, found 219.1388 .

Entry 4. The reaction was heated at $120^{\circ} \mathrm{C}$ for $26 \mathrm{~h}$. The crude product was purified by flash chromatography (using a gradient from 9:1 to 4:1 hexanes/EtOAc) to afford $134 \mathrm{mg}$ of a yellow oil in $70 \%$ yield. $\mathrm{R}_{\mathrm{F}} 0.33\left(2: 1\right.$ hexanes/EtOAc); ${ }^{1} \mathrm{H}$ NMR $\left(500 \mathrm{MHz}, \mathrm{CDCl}_{3}\right)$ $\delta 9.96(\mathrm{~s}, 1 \mathrm{H}), 7.67(\mathrm{~d}, J=7.3 \mathrm{~Hz}, 1 \mathrm{H}), 7.63(\mathrm{~s}, 1 \mathrm{H}), 7.46-7.39(\mathrm{~m}, 2 \mathrm{H}), 6.97(\mathrm{q}, J=7.0$ $\mathrm{Hz}, 1 \mathrm{H}), 3.75$ (s, 2H), 2.33 (s, 3H), 1.97 (d, $J=7.0 \mathrm{~Hz}, 3 \mathrm{H}) ;{ }^{13} \mathrm{C}$ NMR (125 MHz, $\left.\mathrm{CDCl}_{3}\right) \delta 198.9,192.7,141.6,141.2,140.9,136.7,134.9,129.3,129.2,127.8,30.6,25.7$, 15.5; IR (film) 3056, 3007, 2839, 2731, 1697, 1665, 1602, $688 \mathrm{~cm}^{-1}$; HRMS (EI $\left.{ }^{+}\right)$calc'd for $\left[\mathrm{C}_{13} \mathrm{H}_{14} \mathrm{O}_{2}\right]^{+}: m / z 202.0994$, found 202.0990 .

Entry 5. The reaction was heated at $120^{\circ} \mathrm{C}$ for $6.5 \mathrm{~h}$. The crude product was purified by flash chromatography (using a gradient from 9:1 to 4:1 hexanes/EtOAc) to afford $151 \mathrm{mg}$ of a yellow oil in $74 \%$ yield. $\mathrm{R}_{\mathrm{F}} 0.47\left(2: 1\right.$ hexanes/EtOAc); ${ }^{1} \mathrm{H}$ NMR $\left(500 \mathrm{MHz}, \mathrm{CDCl}_{3}\right)$ $\delta 7.44(\mathrm{dd}, J=7.4,1.3 \mathrm{~Hz}, 1 \mathrm{H}), 7.39(\mathrm{~d}, J=8.2 \mathrm{~Hz}, 1 \mathrm{H}), 7.21-7.14, \mathrm{~m}, 2 \mathrm{H}), 6.98(\mathrm{q}, J=$ $7.0 \mathrm{~Hz}, 1 \mathrm{H}), 6.32(\mathrm{~d}, J=0.9 \mathrm{~Hz}, 1 \mathrm{H}), 3.84(\mathrm{~s}, 2 \mathrm{H}), 2.35(\mathrm{~s}, 3 \mathrm{H}), 2.02(\mathrm{~d}, J=7.0 \mathrm{~Hz}) ;{ }^{13} \mathrm{C}$ NMR (125 MHz, $\left.\mathrm{CDCl}_{3}\right) \delta 198.2,156.7,154.8,141.6,138.8,129.0,123.3,122.5,120.4$, 110.9, 102.7, 25.6, 24.4, 15.3; IR (film) 3056, 1668, 1643, 1455, 1254, $751 \mathrm{~cm}^{-1}$; HRMS $\left(\mathrm{EI}^{+}\right)$calc'd for $\left[\mathrm{C}_{14} \mathrm{H}_{14} \mathrm{O}_{2}\right]^{+}: \mathrm{m} / \mathrm{z} 214.0994$, found 214.0989 .

Entry 6. The reaction was heated at $120{ }^{\circ} \mathrm{C}$ for $6 \mathrm{~h}$. The product was obtained in $60 \%$ yield as a 3:1 mixture of the trans and cis isomers, respectively, determined using integration of ${ }^{1} \mathrm{H}$ NMR resonances and confirmed by NOESY. The two isomers were separated by flash chromatography (using a gradient from 9:1 to 2:1 hexanes/EtOAc), 
though the minor isomer could not be obtained free from the major isomer. The major trans isomer was obtained as a gold-colored oil. $\mathrm{R}_{\mathrm{F}} 0.52\left(2: 1\right.$ hexanes/EtOAc); ${ }^{1} \mathrm{H}$ NMR $\left(500 \mathrm{MHz}, \mathrm{CDCl}_{3}\right) \delta 7.35(\mathrm{~d}, J=7.6 \mathrm{~Hz}, 1 \mathrm{H}), 7.24-7.21(\mathrm{~m}, 1 \mathrm{H}), 7.16-7.14(\mathrm{~m}, 2 \mathrm{H}), 7.00$ (q, $J=7.0 \mathrm{~Hz}, 1 \mathrm{H}), 5.54-5.52(\mathrm{~m}, 1 \mathrm{H}), 3.45(\mathrm{~d}, J=1.8 \mathrm{~Hz}, 2 \mathrm{H}), 2.72(\mathrm{t}, J=8.0 \mathrm{~Hz}, 2 \mathrm{H})$, $2.36(\mathrm{~s}, 3 \mathrm{H}), 2.23-2.19(\mathrm{~m}, 2 \mathrm{H}), 1.85(\mathrm{~d}, J=7.0 \mathrm{~Hz}, 3 \mathrm{H}) ;{ }^{13} \mathrm{C} \mathrm{NMR}\left(125 \mathrm{MHz}, \mathrm{CDCl}_{3}\right) \delta$ $199.1,140.9,140.6,136.7,135.5,132.8,127.5,126.8,126.4,123.8,122.5,28.3,27.6$, 25.9, 23.2, 15.1; IR (film) 3056, 2932, 1668, 1429, 1211, $753 \mathrm{~cm}^{-1} ; \mathrm{HRMS}\left(\mathrm{EI}^{+}\right)$calc'd for $\left[\mathrm{C}_{16} \mathrm{H}_{18} \mathrm{O}\right]^{+}: \mathrm{m} / \mathrm{z} 226.1358$, found 226.1359 .

Entry 7. The reaction was heated at $120{ }^{\circ} \mathrm{C}$ for $9 \mathrm{~h}$. The crude product was purified by flash chromatography (using a gradient from 9:1 to 2:1 hexanes/EtOAc) to afford $238 \mathrm{mg}$ of a yellow oil in $71 \%$ yield. $\mathrm{R}_{\mathrm{F}} 0.30$ (2:1 hexanes/EtOAc); ${ }^{1} \mathrm{H}$ NMR $\left(500 \mathrm{MHz}, \mathrm{CDCl}_{3}\right)$ $\delta 7.94(\mathrm{~d}, J=8.2 \mathrm{~Hz}, 1 \mathrm{H}), 7.79(\mathrm{~d}, J=8.0 \mathrm{~Hz}, 2 \mathrm{H}), 7.53-7.48(\mathrm{~m}, 2 \mathrm{H}), 7.41-7.38(\mathrm{~m}$, 2H), $7.30(\mathrm{t}, J=7.5 \mathrm{~Hz}, 1 \mathrm{H}), 7.23(\mathrm{t}, J=7.3 \mathrm{~Hz}, 1 \mathrm{H}), 7.13(\mathrm{~s}, 1 \mathrm{H}), 6.95(\mathrm{q}, J=7.0 \mathrm{~Hz}$, 1H), $3.68(\mathrm{~s}, 2 \mathrm{H}), 2.35(\mathrm{~s}, 3 \mathrm{H}), 1.89(\mathrm{~d}, J=7.0 \mathrm{~Hz}, 3 \mathrm{H}) ;{ }^{13} \mathrm{C} \mathrm{NMR}\left(125 \mathrm{MHz}, \mathrm{CDCl}_{3}\right) \delta$ $198.6,140.8,140.5,138.2,135.5,133.8,131.0,129.3,126.7,124.9,123.4,123.3,121.4$, 119.8, 113.8, 25.7, 20.6, 15.3; IR (film) 3064, 1665, 1448, 1364, 1175, 1120, 748, 724 $\mathrm{cm}^{-1}$; HRMS $\left(\mathrm{EI}^{+}\right)$calc'd for $\left[\mathrm{C}_{20} \mathrm{H}_{19} \mathrm{NO}_{3} \mathrm{~S}\right]^{+}: \mathrm{m} / z$ 353.1086, found 353.1081.

Entry 8. The reaction was heated at $120{ }^{\circ} \mathrm{C}$ for $6 \mathrm{~h}$. The crude product was purified by flash chromatography (using a gradient from 9:1 to 2:1 hexanes/EtOAc) to afford $185 \mathrm{mg}$ of a yellow oil in $52 \%$ yield. $\mathrm{R}_{\mathrm{F}} 0.63\left(1: 2\right.$ hexanes/EtOAc); ${ }^{1} \mathrm{H} \mathrm{NMR}\left(500 \mathrm{MHz}, \mathrm{CDCl}_{3}\right)$ $\delta 7.83(\mathrm{~d}, J=8.0 \mathrm{~Hz}, 2 \mathrm{H}), 7.41(\mathrm{~s}, 1 \mathrm{H}), 7.29(\mathrm{~d}, J=8.0 \mathrm{~Hz}, 2 \mathrm{H}), 6.88(\mathrm{q}, J=7.0 \mathrm{~Hz}, 1 \mathrm{H})$, $6.84(\mathrm{~d}, J=2.1 \mathrm{~Hz}, 1 \mathrm{H}), 3.68(\mathrm{~s}, 3 \mathrm{H}), 3.45(\mathrm{~s}, 2 \mathrm{H}), 2.41(\mathrm{~s}, 3 \mathrm{H}), 2.33(\mathrm{~s}, 3 \mathrm{H}), 1.94(\mathrm{~d}, J=$ $7.0 \mathrm{~Hz}, 3 \mathrm{H}) ;{ }^{13} \mathrm{C}$ NMR $\left(125 \mathrm{MHz}, \mathrm{CDCl}_{3}\right) \delta 198.7,159.3,144.9,141.3,140.4,136.1$, 
$129.5,128.2,126.5,124.6,124.2,123.7,51.8,25.6,22.0,21.8,15.2$; IR (film) 3134 , $1731,1665,1229,1190,1177,1094,671 \mathrm{~cm}^{-1}$; HRMS $\left(\mathrm{EI}^{+}\right)$calc'd for $\left[\mathrm{C}_{19} \mathrm{H}_{21} \mathrm{NO}_{5} \mathrm{~S}\right]^{+}$: $\mathrm{m} / \mathrm{z} 375.1140$, found 375.1139 .

Entry 9. The reaction was heated at $120^{\circ} \mathrm{C}$ for $14 \mathrm{~h}$. The crude product was purified by flash chromatography (using a gradient from 2:1 to 1:2 hexanes/EtOAc) to afford $165 \mathrm{mg}$ of a yellow oil in $77 \%$ yield. $\mathrm{R}_{\mathrm{F}} 0.31\left(1: 2\right.$ hexanes/EtOAc); ${ }^{1} \mathrm{H} \mathrm{NMR}\left(500 \mathrm{MHz}, \mathrm{CDCl}_{3}\right)$ $\delta 8.76(\mathrm{~d}, J=2.1 \mathrm{~Hz}, 1 \mathrm{H}), 8.31(\mathrm{~d}, J=8.5 \mathrm{~Hz}, 1 \mathrm{H}), 8.15(\mathrm{~s}, 1 \mathrm{H}), 7.83(\mathrm{~d}, J=8.2 \mathrm{~Hz}, 1 \mathrm{H})$, 7.77-7.74 (m, 1H), 7.63-7.60 (m, 1H), $7.02(\mathrm{q}, J=7.0 \mathrm{~Hz}, 1 \mathrm{H}), 3.87(\mathrm{~s}, 2 \mathrm{H}), 2.33(\mathrm{~s}, 3 \mathrm{H})$, $2.04(\mathrm{~d}, J=7.0 \mathrm{~Hz}, 3 \mathrm{H}) ;{ }^{13} \mathrm{C}$ NMR $\left(125 \mathrm{MHz}, \mathrm{CDCl}_{3}\right) \delta 198.7,151.5,146.5,141.1$, $140.9,134.7,132.9,128.9,128.8,128.2,127.5,126.7,28.3,25.6,15.5$; IR (film) 1666, $1641,1495,1423,1387,1279,789,756 \mathrm{~cm}^{-1}$; HRMS $\left(\mathrm{EI}^{+}\right)$calc'd for $\left[\mathrm{C}_{15} \mathrm{H}_{15} \mathrm{NO}\right]^{+}: \mathrm{m} / \mathrm{z}$ 225.1154, found 225.1154.

\section{Determination of Thermodynamic versus Kinetic Control of the Olefin Geometry} (Scheme S3). Compound S1 $(50.0 \mathrm{mg}, 0.29 \mathrm{mmol})$ was placed in a $10 \mathrm{~mL}$ quartz testtube. The test-tube was capped with a rubber septum which was wrapped in Teflon tape then evacuated briefly (ca. $5 \mathrm{sec}$ ) and backfilled with $\mathrm{N}_{2}(3 \mathrm{X})$. To the tube was added anhydrous THF $(5 \mathrm{~mL})$ and the resulting solution irradiated at $310 \mathrm{~nm}$ in a Luzchem ${ }^{\circledR}$ photoreactor for $5 \mathrm{~h}$ (Scheme S3). The resulting mixture was concentrated under reduced pressure. NMR analysis indicated isomerization of the starting material (E-isomer) to the Z-isomer in a ratio of 3:1. 


\section{Scheme S3.}

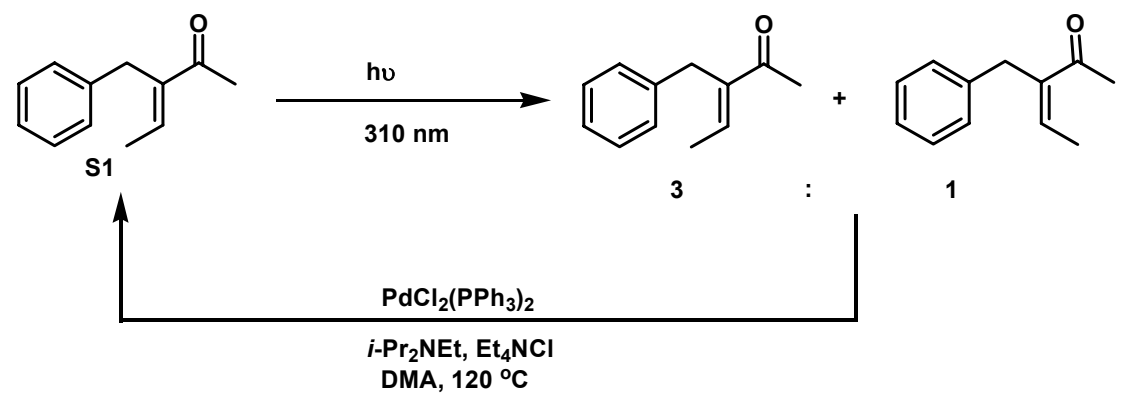

To establish whether the E-isomer is the thermodynamic product, the crude product from the photolysis reaction was subjected to our optimized coupling conditions. The crude product was dissolved in DMA $(1.5 \mathrm{~mL})$ and to the mixture was added Hünig's base $(150.0 \mu \mathrm{L}, 0.86 \mathrm{mmol})$. The mixture was placed in a sealed tube containing $\mathrm{PdCl}_{2}\left(\mathrm{PPh}_{3}\right)_{2}$ $(6.0 \mathrm{mg}, 0.0086 \mathrm{mmol})$ and $\mathrm{Et}_{4} \mathrm{NCl}(0.33 \mathrm{mmol})$, then evacuated and backfilled with $\mathrm{N}_{2}$ ( $3 \mathrm{X})$. The tube was then inserted in an oil bath preheated to $120^{\circ} \mathrm{C}$ and stirred for $5 \mathrm{~h}$. After cooling, ether $(10 \mathrm{~mL})$ was added. The ether layer was washed with $1 \%$ aqueous $\mathrm{HCl}(2 \times 5 \mathrm{~mL})$. The aqueous layers were combined and extracted with ether $(2 \times 5 \mathrm{~mL})$. The combined ethereal phase was washed with $1 \%$ aqueous $\mathrm{HCl}(5 \mathrm{~mL})$ and brine (5 $\mathrm{mL}$ ), dried over $\mathrm{MgSO}_{4}$ and concentrated in vacuo to yield an oily product. NMR analysis of the crude product indicated only the E-isomer supporting its assignment as the thermodynamic product.

\section{Synthetic Utility of the Anomalous Heck reaction}

a) Ring Expansion

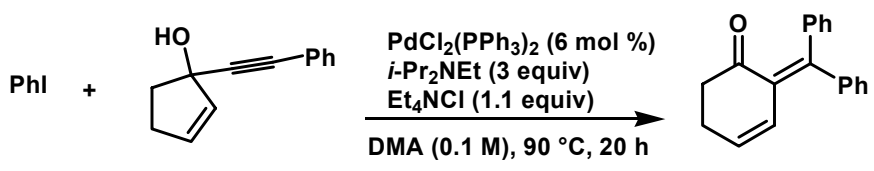


The reaction was run for $20 \mathrm{~h}$ at $90{ }^{\circ} \mathrm{C}$ to give a yellow oil in $54 \%$ yield. $\mathrm{R}_{\mathrm{F}} 0.19$ (4:1 hexanes:EtOAc); ${ }^{1} \mathrm{H}$ NMR (500 MHz, $\left.\mathrm{CDCl}_{3}\right) \delta$ 7.43-7.41 (m, 2H), 6.03-6.01 (m, 1H), 5.91-5.89 (m, 1H), 2.62-2.45 (m, 3H), 2.28-2.23(m, 1H), $2.22(\mathrm{br}, \mathrm{s}, 1 \mathrm{H}) ;{ }^{13} \mathrm{C}$ NMR $(125$ $\left.\mathrm{MHz}, \mathrm{CDCl}_{3}\right) \delta 135.3,134.9,131.8,128.44,128.37,122.8,91.7,84.5,78.4,41.2,31.2$ IR (film) 3050, 1694, 1550, 1488, 1442, 1158, 1110, 771, $699 \mathrm{~cm}^{-1}$; HRMS (EI $\left.{ }^{+}\right)$calc'd for $\left[\mathrm{C}_{12} \mathrm{H}_{14} \mathrm{O}\right]^{+}: \mathrm{m} / z$ 260.1201, found 260.1194 .

b)Annulation Reaction

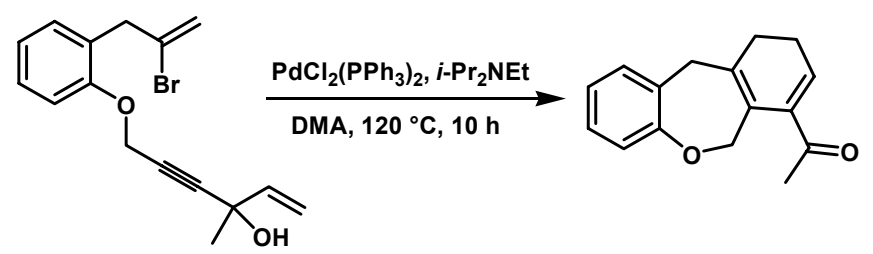

Nitrogen was bubbled through the reaction mixture for $5 \mathrm{~min}$. prior to heating. The Schlenk vessel was then evacuated and backfilled with $\mathrm{N}_{2}(3 \mathrm{x})$ and heated at $120^{\circ} \mathrm{C}$ for $10 \mathrm{~h}$. A 9:1 ratio of the cyclohexadiene (shown) and the corresponding aromatized compound was obtained in $55 \%$ yield as determined by integration of ${ }^{1} \mathrm{H}$ NMR resonances using 1,2-dichloroethane as an internal standard. Characterization of the major (unaromatized) product is reported. $\mathrm{R}_{\mathrm{F}} 0.35$ (2:1 hexanes:EtOAc); ${ }^{1} \mathrm{H}$ NMR (500 $\left.\mathrm{MHz}, \mathrm{CDCl}_{3}\right) \delta$ 7.18-7.14 (m, 1H), $7.04(\mathrm{~d}, J=6.9 \mathrm{~Hz}, 1 \mathrm{H}), 6.98-6.94(\mathrm{~m}, 2 \mathrm{H}), 6.83(\mathrm{t}, J$ $=4.9 \mathrm{~Hz}, 1 \mathrm{H}), 4.89(\mathrm{~s}, 2 \mathrm{H}), 3.67(\mathrm{~s}, 2 \mathrm{H}), 2.35-2.31(\mathrm{~m}, 5 \mathrm{H}), 2.24-2.20(\mathrm{~m}, 2 \mathrm{H}) ;{ }^{13} \mathrm{C} \mathrm{NMR}$ (125 MHz, $\left.\mathrm{CDCl}_{3}\right), \delta 199.0,159.2,140.2,137.8,135.9,130.2,129.7,128.2,127.3$, 123.1, 120.8, 71.0, 39.4, 29.3, 27.2, 23.5; IR (film) 2930, 2873, 1670, 1401, 1261, 1240, $1005 \mathrm{~cm}^{-1}$; HRMS $\left(\mathrm{EI}^{+}\right)$calc'd for $\left[\mathrm{C}_{16} \mathrm{H}_{16} \mathrm{O}_{2}\right]^{+}: \mathrm{m} / z$ 240.1150, found 240.1147 . 


\section{Synthesis of Substrates}

\section{Synthesis of 3-phenyl-penta-1,4-dien-3-ol.}

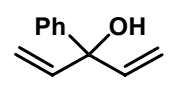

In the literature, ${ }^{5}$ 3-phenyl-penta-1,4-dien-3-ol is prepared from addition of vinyl magnessium bromide to methyl benzoate in the presence of cerium trichloride albeit in low yields $(35 \%)$. A modified procedure for the preparation of organocerium reagent ${ }^{6}$ followed by addition of vinyl magnesium bromide was adopted resulting in high yields of the desired compound. Cerium(III)chloride heptahydrate $(22.0 \mathrm{~g}, 59.0 \mathrm{mmol})$ was heated under vacuum at $90{ }^{\circ} \mathrm{C}$ for $2 \mathrm{~h}$ with intermittent shaking. The resulting powder was heated overnight (ca. $10 \mathrm{~h}$ ) at $120{ }^{\circ} \mathrm{C}$ and then additionally at $140{ }^{\circ} \mathrm{C}$ for $2 \mathrm{~h}$ to give a free flowing white powder that was cooled under nitrogen. To the powder was added tetrahydrofuran $(120 \mathrm{~mL})$ and the mixture was stirred at $23{ }^{\circ} \mathrm{C}$ for $6 \mathrm{~h}$. Methyl benzoate (2.5 mL, $20.0 \mathrm{mmol}$ ) was added and the mixture was stirred for $2 \mathrm{~h}$ resulting in a heterogeneous solution. The mixture was cooled to $-78{ }^{\circ} \mathrm{C}$ and vinyl magnesium bromide (50.0 mL, $50.0 \mathrm{mmol}$ ) was slowly added via syringe. The mixture was stirred at $-78{ }^{\circ} \mathrm{C}$ for $10 \mathrm{~min}$ at which time the cold bath was removed. The reaction was further stirred for $30 \mathrm{~min}$ and quenched with $1 \%$ aqueous acetic acid $(50 \mathrm{~mL})$. Tetrahydrofuran was removed under reduced pressure and the aqueous layer extracted with ether $(3 \times 50 \mathrm{~mL})$. The combined ethereal phase was washed with brine $(50 \mathrm{~mL}), \mathrm{NaHCO}_{3}(50 \mathrm{~mL}$; Caution! STRONG EFFERVESCENCE!) and brine (50 mL). Drying over magnesium sulfate and concentration under reduced pressure gave the crude product which was purified by column chromatography (4:1 hexanes: EtOAc) to give $2.36 \mathrm{~g}$ of a clear colorless liquid in 74\% yield. $\mathrm{R}_{\mathrm{F}} 0.57$ (2:1 hexanes:EtOAc); ${ }^{1} \mathrm{H} \mathrm{NMR}\left(500 \mathrm{MHz}, \mathrm{CDCl}_{3}\right)$ 
$\delta$ 7.47-7.45 (m, 2H), $7.35(\mathrm{~m}, 2 \mathrm{H}), 7.28-7.25(\mathrm{~m}, 1 \mathrm{H}), 6.21(\mathrm{dd}, J=10.5,17.0 \mathrm{~Hz}, 2 \mathrm{H})$, $5.35(\mathrm{dd}, J=1.5,17.0 \mathrm{~Hz}, 2 \mathrm{H}), 5.25(\mathrm{dd}, J=1.5,10.5 \mathrm{~Hz}, 2 \mathrm{H}), 2.0(\mathrm{br}, 1 \mathrm{H}) ;{ }^{13} \mathrm{C} \mathrm{NMR}$ $\left(125 \mathrm{MHz}, \mathrm{CDCl}_{3}\right) \delta 144.2,142.5,128.3,127.5,126.2,114.1,77.8$; IR (film) 3446, 3086, $3060,3053,1677,1637,1491,1448,1408,1333,1292,1164,1074,994,924,701 \mathrm{~cm}^{-1}$ HRMS $\left(\mathrm{EI}^{+}\right)$calc'd for $\left[\mathrm{C}_{11} \mathrm{H}_{12} \mathrm{O}\right]^{+}: \mathrm{m} / z, 160.088815$ found 160.086118 .

\section{Synthesis of 3-methyl-1-phenylpenta-1,4-dien-3-ol.}

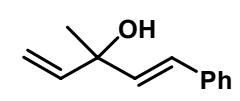

trans-4-Phenyl-3-buten-2-one $(1.0 \mathrm{~g}, 6.84 \mathrm{mmol})$ was dissolved in ether $(40 \mathrm{~mL})$ and the solution cooled to $-78{ }^{\circ} \mathrm{C}$. Vinyl magnesium bromide $(8.0 \mathrm{~mL}, 8.0 \mathrm{mmol})$ was slowly added and the mixture stirred at $-78{ }^{\circ} \mathrm{C}$ for $10 \mathrm{~min}$. The cold bath was removed and the mixture was stirred for $1 \mathrm{~h}$ with warming to $23{ }^{\circ} \mathrm{C}$. The reaction was quenched by addition of saturated aqueous $\mathrm{NH}_{4} \mathrm{Cl}(20 \mathrm{~mL})$ and the organic layer was separated and washed with saturated aqueous $\mathrm{NH}_{4} \mathrm{Cl}(20 \mathrm{~mL})$. The aqueous layers were combined and extracted with ether $(2 \times 30 \mathrm{~mL})$. The combined ethereal phase was washed with brine $(30 \mathrm{~mL})$ then dried over $\mathrm{MgSO}_{4}$ and concentrated in vacuo. The product was purified by flash column chromatography (4:1 hexanes:EtOAc) to give $1.07 \mathrm{~g}$ of a yellow oil in $89 \%$ yield. $\mathrm{R}_{\mathrm{F}} 0.60$ (2:1 hexanes:EtOAc); ${ }^{1} \mathrm{H}$ NMR $\left(500 \mathrm{MHz}, \mathrm{CDCl}_{3}\right) \delta 7.39$ (app. d, $J=7.0$ Hz, 2H), 7.31 (app. d, $J=7.0 \mathrm{~Hz}, 2 \mathrm{H}), 7.23$ (app. d, $J=7.0 \mathrm{~Hz}, 1 \mathrm{H}), 6.61$ (d, $J=16.0 \mathrm{~Hz}$, 1H), $6.31(\mathrm{~d}, J=16.0 \mathrm{~Hz}, 1 \mathrm{H}), 6.05(\mathrm{dd}, J=10.5,17.5 \mathrm{~Hz}, 1 \mathrm{H}), 5.32(\mathrm{dd}, J=1.0,17.0$ $\mathrm{Hz}, 1 \mathrm{H}), 5.13(\mathrm{dd}, J=1.0,10.5 \mathrm{~Hz}, 1 \mathrm{H}), 1.49(\mathrm{~s}, 3 \mathrm{H}) ;{ }^{13} \mathrm{C} \mathrm{NMR}\left(125 \mathrm{MHz}, \mathrm{CDCl}_{3}\right) \delta$ 143.8, 136.9, 135.2, 128.7, 128.0, 127.7, 126.6, 112.7, 73.6, 28.2; IR (film) 3385, 3026, 2977, 1638, 1599, 1493, 1448, 1366, 1157, 1103, 992, 921, 748, $693 \mathrm{~cm}^{-1}$; HRMS $\left(\mathrm{EI}^{+}\right)$ calc'd for $\left[\mathrm{C}_{12} \mathrm{H}_{14} \mathrm{O}\right]^{+}: m / z$ 174.104465, found 174.104272. 


\section{Synthesis of Phenylprop-2-en-1-one.}

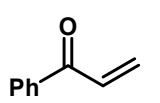

A solution of N-methoxy-N-methyl-benzamide $(870.0 \mathrm{mg}, 5.27 \mathrm{mmol})$ in THF (30.0 mL) was cooled to $-78{ }^{\circ} \mathrm{C}$. Vinyl magnesium bromide $(6.0 \mathrm{~mL}, 6.0 \mathrm{mmol})$ was slowly added, the mixture stirred at $-78{ }^{\circ} \mathrm{C}$ for $10 \mathrm{~min}$ and the cold bath removed. The mixture was stirred for a further $5 \mathrm{~h}$ and the reaction quenched with saturated aqueous $\mathrm{NH}_{4} \mathrm{Cl}(20 \mathrm{~mL})$. The aqueous layer was separated and extracted with ethyl acetate $(2 \times 20 \mathrm{~mL})$. The combined organic phase was washed with brine $(30 \mathrm{~mL})$ then dried over $\mathrm{MgSO}_{4}$ and concentrated in vacuo. The product was purified by flash column chromatography (4:1 hexanes:EtOAc) to give $485 \mathrm{mg}$ of a colorless liquid in $70 \%$ yield. All the characterization data was consistent with literature data. ${ }^{8}$

\section{Synthesis of 3,5-diphenylpent-1-en-4-yn-3-ol .}

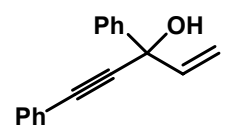

To a solution containing phenylacetylene $(280.0 \mu \mathrm{L}, 2.55 \mathrm{mmol})$ was added ethylmagnesium bromide $(2.6 \mathrm{~mL}, 2.6 \mathrm{mmol}) .{ }^{9}$ The mixture was stirred for $2 \mathrm{~h}$ at $23{ }^{\circ} \mathrm{C}$ and then heated for $1 \mathrm{~h}$ at reflux. The solution was then added to a mixture of 1 Phenylprop-2-en-1-one $(300.0 \mathrm{mg}, 2.27 \mathrm{mmol})$ and anhydrous $\mathrm{CeCl}_{3}(1.9 \mathrm{~g}, 7.18 \mathrm{mmol})$ in THF $(15.0 \mathrm{ml})$ at $-78{ }^{\circ} \mathrm{C}$. The mixture was stirred at $-78{ }^{\circ} \mathrm{C}$ for $10 \mathrm{~min}$, the cold bath removed and the mixture stirred for a further $1 \mathrm{~h}$. The reaction was quenched with $1 \%$ aqueous acetic acid $(20 \mathrm{~mL})$. Tetrahydrofuran was removed under reduced pressure and the aqueous layer extracted with ethyl acetate $(3 \times 20 \mathrm{~mL})$. The combined organic phase was washed with brine $(20 \mathrm{~mL}), \mathrm{NaHCO}_{3}(50 \mathrm{~mL}$; Caution! STRONG 
EFFERVESCENCE!) and brine $(50 \mathrm{~mL})$. Drying over magnesium sulfate and concentration under reduced pressure gave the crude product which was purified by column chromatography (4:1 hexanes: EtOAc) to give $338 \mathrm{mg}$ of a yellow liquid in $64 \%$ yield. $\mathrm{R}_{\mathrm{F}} 0.30$ (4:1 hexanes:EtOAc); ${ }^{1} \mathrm{H}$ NMR $\left(500 \mathrm{MHz}, \mathrm{CDCl}_{3}\right) ; \delta$ 7.71-7.69 (m, 2H), 7.51-7.49 (m, 2H), 7.40-7.30 (m, 6H), $6.15(\mathrm{dd}, J=10.0,17.0 \mathrm{~Hz}, 1 \mathrm{H}), 5.68$ (dd, $J=1.0$, $17.0 \mathrm{~Hz}), 5.24(\mathrm{dd}, J=1.0,10.0 \mathrm{~Hz}), 2.64(\mathrm{~s}, 1 \mathrm{H}) ;{ }^{13} \mathrm{C} \mathrm{NMR}\left(125 \mathrm{MHz}, \mathrm{CDCl}_{3}\right) \delta 143.2$, 141.6, 132.0, 128.9, 128.6, 128.5, 128.2, 126.0, 122.5, 114.2, 89.8, 87.6, 73.7; IR (film) 3428, 1638, 1489, 1447, 1028, 984, 930, 757, $692 \mathrm{~cm}^{-1}$; HRMS $\left(\mathrm{EI}^{+}\right)$calc'd for $\left[\mathrm{C}_{12} \mathrm{H}_{14} \mathrm{O}\right]^{+}: m / z 234.1045$, found 234.1041.

\section{Synthesis of 1-(2-phenylethynyl)cyclopent-2-enol.}

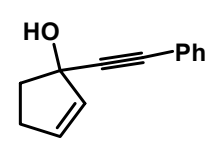

To a solution containing phenylacetylene $(1.3 \mathrm{~mL}, 11.84 \mathrm{mmol})$ in THF $(70.0 \mathrm{~mL})$ at -78 ${ }^{\circ} \mathrm{C}$ was added butyllithium $(5.3 \mathrm{~mL}, 13.25 \mathrm{mmol})$. The mixture was stirred for $40 \mathrm{~min}$ before adding cyclopent-2-enone $(1.0 \mathrm{~mL}, 11.94 \mathrm{mmol})$ and stirring the mixture at $-78{ }^{\circ} \mathrm{C}$ for $1 \mathrm{~h}$. The cold bath was removed and the mixture stirred for a further $2 \mathrm{~h}$. The reaction was quenched with saturated aqueous $\mathrm{NH}_{4} \mathrm{Cl}(50 \mathrm{~mL})$. The aqueous layer was separated and extracted with ethyl acteate $(3 \times 20 \mathrm{~mL})$. The combined organic phase was washed with saturated aqueous $\mathrm{NH}_{4} \mathrm{Cl}(50 \mathrm{~mL})$, brine $(30 \mathrm{~mL})$ then dried over $\mathrm{MgSO}_{4}$ and concentrated in vacuo. The product was purified by flash column chromatography (4:1 hexanes:EtOAc) to give $1.53 \mathrm{~g}$ of a yellow semi solid in $70 \%$ yield. $\mathrm{R}_{\mathrm{F}} 0.19$ (4:1 hexanes:EtOAc); ${ }^{1} \mathrm{H}$ NMR (500 MHz, $\left.\mathrm{CDCl}_{3}\right) \delta$ 7.43-7.41 (m, 2H), 6.03-6.01 (m, $\left.1 \mathrm{H}\right)$, 5.91-5.89 (m, 1H), 2.62-2.45 (m, 3H), 2.28-2.23 (m, 1H), 2.22 (br, s, $1 \mathrm{H}) ;{ }^{13} \mathrm{C}$ NMR (125 
$\left.\mathrm{MHz}, \mathrm{CDCl}_{3}\right) \delta 135.3,134.9,131.8,128.44,128.37,122.8,91.7,84.5,78.4,41.2,31 ; \mathrm{IR}$ (film) 3365, 3057, 2931, 1671, 1489, 1443, 1345, 1046, 956, 757, $691 \mathrm{~cm}^{-1}$; HRMS (EI ${ }^{+}$) calc'd for $\left[\mathrm{C}_{16} \mathrm{H}_{16} \mathrm{O}\right]^{+}: \mathrm{m} / z$ 184.0888, found 184.0879 .

\section{Scheme S4.}

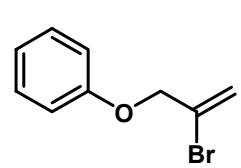

S7

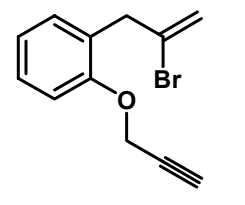

S9

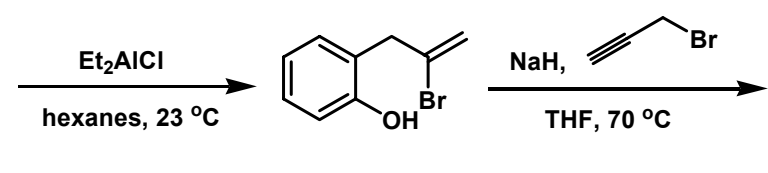

S8
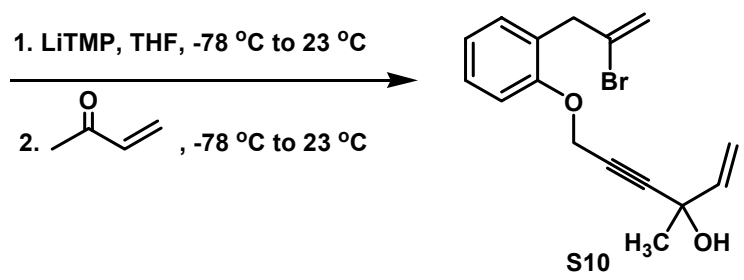

Synthesis of S8. $\mathrm{Et}_{2} \mathrm{AlCl}(10.8 \mathrm{~mL}, 1.0 \mathrm{M}$ soln. in hexanes) was added to a solution of 1[(2-bromoprop-2-enyl)oxy]benzene ${ }^{10}(\mathbf{S} 7)(1.15 \mathrm{~g}, 5.40 \mathrm{mmol})$ in freshly distilled hexanes $(50 \mathrm{~mL})$ at $0{ }^{\circ} \mathrm{C}$. The solution was allowed to warm to $23{ }^{\circ} \mathrm{C}$ and was stirred 15 h. The reaction mixture was quenched by the addition of a saturated solution of $\mathrm{Na} / \mathrm{K}$ tartarate tetrahydrate $(10 \mathrm{~mL})$ and extracted into EtOAc $(3 \times 35 \mathrm{~mL})$. The combined organic layers were washed with water $(40 \mathrm{~mL})$ and brine $(40 \mathrm{~mL})$, dried over $\mathrm{MgSO}_{4}$, and concentrated in vacuo. The crude product was purified by flash chromatography (using a gradient from 9:1 to 4:1 hexanes/EtOAc) to afford $865 \mathrm{mg}$ ( $75 \%$ yield) of a light brown oil. $\mathrm{R}_{\mathrm{F}} 0.47$ (2:1 hexanes/EtOAc); ${ }^{1} \mathrm{H}$ NMR $\left(500 \mathrm{MHz}, \mathrm{CDCl}_{3}\right) \delta$ 7.20-7.17 (m, 2H), $6.93(\mathrm{dt}, J=2.5 \mathrm{~Hz}, 1.0 \mathrm{~Hz}, 1 \mathrm{H}) 6.82-6.80(\mathrm{~m}, 1 \mathrm{H}), 5.56(\mathrm{~m}, 1 \mathrm{H}), 5.52(\mathrm{~m}, 1 \mathrm{H})$, 4.92 (bs, $1 \mathrm{H}), 3.79$ (s, 2H); ${ }^{13} \mathrm{C}$ NMR (125 MHz, $\left.\mathrm{CDCl}_{3}\right), \delta$ 153.8, 131.8, 131.3, 128.7, 123.7, 121.2, 118.0, 116.0, 42.2; IR (film) 1620, 1593, 1506, 1456, 1217, $1096 \mathrm{~cm}^{-1}$; HRMS $\left(\mathrm{EI}^{+}\right)$calc'd for $\left[\mathrm{C}_{9} \mathrm{H}_{9} \mathrm{OBr}\right]^{+}: \mathrm{m} / z 211.9837$, found 211.9840 . 
Synthesis of S9. $\mathrm{NaH}(60 \%$ disp. in mineral oil, $196 \mathrm{mg}, 4.89 \mathrm{mmol})$ was added to a solution of alcohol S8 (695 mg, $3.26 \mathrm{mmol})$ in THF (16 mL) and stirred $15 \mathrm{~min}$. Propargyl bromide ( $80 \mathrm{wt} \%$ soln. in toluene, $0.54 \mathrm{~mL}, 4.89 \mathrm{mmol}$ ) was then added and the reaction mixture heated in a sealed Schlenk vessel at $70{ }^{\circ} \mathrm{C}$ for $11 \mathrm{~h}$. The reaction mixture was quenched by the addition of saturated $\mathrm{NH}_{4} \mathrm{Cl}(15 \mathrm{~mL})$ and extracted with $\mathrm{Et}_{2} \mathrm{O}(3 \times 15 \mathrm{~mL})$. The combined organic layers were washed with $10 \% \mathrm{~K}_{2} \mathrm{CO}_{3}(15 \mathrm{~mL})$, $\mathrm{H}_{2} \mathrm{O}(15 \mathrm{~mL})$, and brine $(15 \mathrm{~mL})$, dried over $\mathrm{MgSO}_{4}$, and concentrated in vacuo. The crude product was purified by flash chromatography (using a gradient from 9:1 to 4:1 hexanes/EtOAc) to afford $587 \mathrm{mg}$ of a yellow liquid in $72 \%$ yield. $\mathrm{R}_{\mathrm{F}} 0.45(2: 1$ hexanes/EtOAc); ${ }^{1} \mathrm{H}$ NMR (500 MHz, $\left.\mathrm{CDCl}_{3}\right) \delta$ 7.29-7.22 (m, 2H), 7.01-6.97 (m, 2H), $5.51(\mathrm{~d}, J=1.2 \mathrm{~Hz}, 1 \mathrm{H}), 5.48(\mathrm{~s}, 1 \mathrm{H}), 4.72(\mathrm{~d}, J=2.4 \mathrm{~Hz}, 2 \mathrm{H}), 3.79(\mathrm{~s}, 2 \mathrm{H}), 2.50(\mathrm{t}, J=$ $2.3 \mathrm{~Hz}, 1 \mathrm{H}) ;{ }^{13} \mathrm{C}$ NMR $\left(125 \mathrm{MHz}, \mathrm{CDCl}_{3}\right), \delta 155.7,132.0,131.0,128.4,126.5,121.6$, 117.9, 112.4, 78.8, 75.5, 56.2, 41.8; IR (film) 1620, 1491, 1454, 1222, 1107, $1026 \mathrm{~cm}^{-1}$; HRMS $\left(\mathrm{EI}^{+}\right)$calc'd for $\left[\mathrm{C}_{12} \mathrm{H}_{11} \mathrm{OBr}\right]^{+}: m / z 249.9993$, found 249.9991.

Synthesis of S10. A solution of alkyne S9 in THF $(10 \mathrm{~mL})$ was added at $-78{ }^{\circ} \mathrm{C}$ to a solution of LiTMP, which had been generated by the addition of $n$-BuLi $(1.1 \mathrm{~mL}, 2.8$ mmol, 2.5 $\mathrm{M}$ soln. in hexanes) to 2,2,6,6-tetramethyl piperidine $(0.47 \mathrm{~mL}, 2.8 \mathrm{mmol})$ in THF (15 mL) at $-78^{\circ} \mathrm{C}$ with stirring at $23{ }^{\circ} \mathrm{C}$ for $2.5 \mathrm{~h}$. The resulting solution was allowed to warm to $23{ }^{\circ} \mathrm{C}$ and stirred an additional $3 \mathrm{~h}$. Methyl vinyl ketone $(245 \mu \mathrm{L}$, $3.02 \mathrm{mmol}$ ) was then added at $-78^{\circ} \mathrm{C}$, and the mixture stirred for $11 \mathrm{~h}$ with warming to 23 ${ }^{\circ} \mathrm{C}$. Saturated $\mathrm{NH}_{4} \mathrm{Cl}(25 \mathrm{~mL})$ was then added, and the mixture was extracted with EtOAc ( $3 \times 25 \mathrm{~mL})$. The combined organic layers were washed with water and brine, dried over $\mathrm{MgSO}_{4}$, and concentrated in vacuo. The crude product was purified by flash 
chromatography (using a gradient from 9:1 to 4:1 hexanes/EtOAc) to afford $447 \mathrm{mg}$ of a yellow liquid in $56 \%$ yield. $\mathrm{R}_{\mathrm{F}} 0.40\left(2: 1\right.$ hexanes/EtOAc); ${ }^{1} \mathrm{H}$ NMR $\left(500 \mathrm{MHz}, \mathrm{CDCl}_{3}\right) \delta$ 7.27-7.24 (m, 1H), 7.23-7.21 (m, 1H), 6.99-6.96 (m, 2H), $5.93(\mathrm{dd}, J=17.1 \mathrm{~Hz}, 10.3 \mathrm{~Hz}$, 1H), 5.50-5.41 (m, 3H), $5.10(J=10.3 \mathrm{~Hz}, 0.9 \mathrm{~Hz}, 1 \mathrm{H}), 4.76(\mathrm{~s}, 2 \mathrm{H}), 3.78(\mathrm{~s}, 2 \mathrm{H}), 2.05$

(bs, 1H), $1.54(\mathrm{~s}, 3 \mathrm{H}) ;{ }^{13} \mathrm{C}$ NMR (125 MHz, $\left.\mathrm{CDCl}_{3}\right), \delta$ 155.8, 141.6, 132.1, 131.0, 128.4, 126.5, 121.6, 117.9, 114.2, 112.6, 89.1, 80.0, 68.4, 56.5, 41.9, 29.9; IR (film) 2984, 1629, $1600,1492,1455,1224,1110 \mathrm{~cm}^{-1}$; HRMS $\left(\mathrm{EI}^{+}\right)$calc'd for $\left[\mathrm{C}_{16} \mathrm{H}_{17} \mathrm{O}_{2} \mathrm{Br}\right]^{+}: \mathrm{m} / z$ 320.0412 , found 320.0415 .

\section{References:}

1. (a) Jeffrey, T. Synthesis 1987, 1, 70-71. (b) Larock, R. C.; Baker, B. E. Tetrahedron Lett. 1988, 29, 905-908. (c) Hegedus, L. S. Synthetic Applications of Complexes Containing Metal-Carbon $\sigma$-Bonds. In Transition Metals in the Synthesis of Complex Organic Molecules, $2^{\text {nd }}$ ed; University Science Books: Sausalito, California, 1999; pp. 97.

2. Hatanaka, M.; Himeda, Y.; Imashiro, R.; Tanaka, Y.; Ueda, I. J. Org. Chem. 1994, 59, 111-119.

3. (a) Saito, S.; Kano, T.; Hatanaka, K.; Yamamoto, H. J. Org. Chem. 1997, 62, 5651-5656 (b) Bonnert, R. V.; Jenkins, P. R. J. Chem. Soc., Perkin Trans 1, 1989, $3,413-418$.

4. Lee, P. H.; Lee, S. W.; Seomoon, D. Org. Lett. 2003, 5, 3641-3644.

5. Imamoto, T.; Takiyama, N.; Nakamura, K.; Hatajima, T.; Kamiya, K. J. Am. Chem. Soc. 1989, 111, 4392-4398.

6. Takeda, N.; Imamoto, T. Org. Syn. 1999, 76, 228-238. 
7. Marson, C. M.; Harper, S. J. Org. Chem. 1998, 63, 9223-9231.

8. Lee, P. H.; Lee, S. W.; Seomoon, D. Org. Lett. 2003, 5, 4963-4966.

9. Padwa, A.; Pulwer, M. J.; Rosennthal, R. J. J. Org. Chem. 1984, 49, 856-862.

10. Organ, M. G.; Arvanitis, E. A.; Dixon, C. E.; Cooper, J. T. J. Am. Chem. Soc. 2002, 124, 1288-1294. 
Ndungu, Larson, and Sarpong, Supporting Information 25

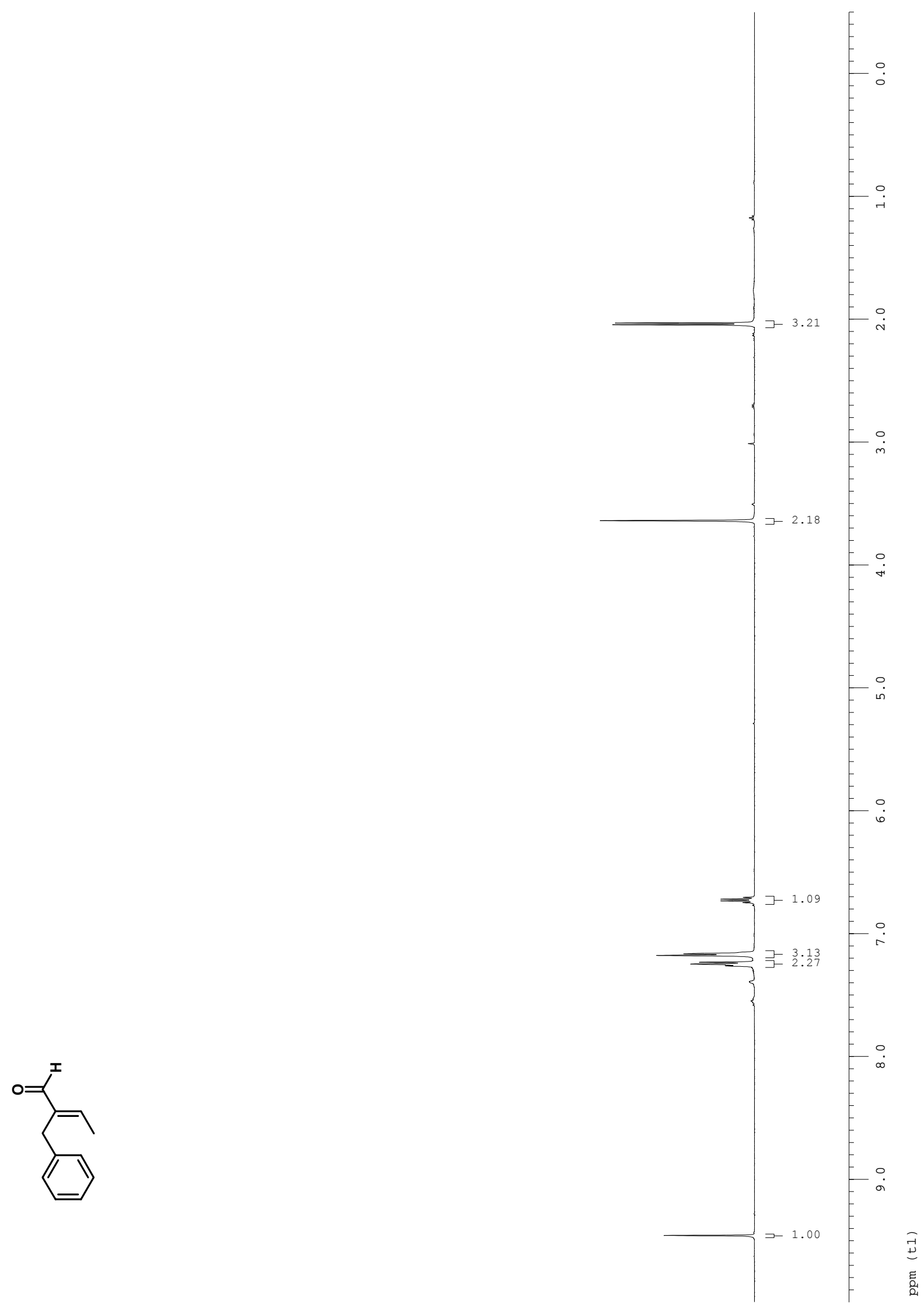


Ndungu, Larson, and Sarpong, Supporting Information 26

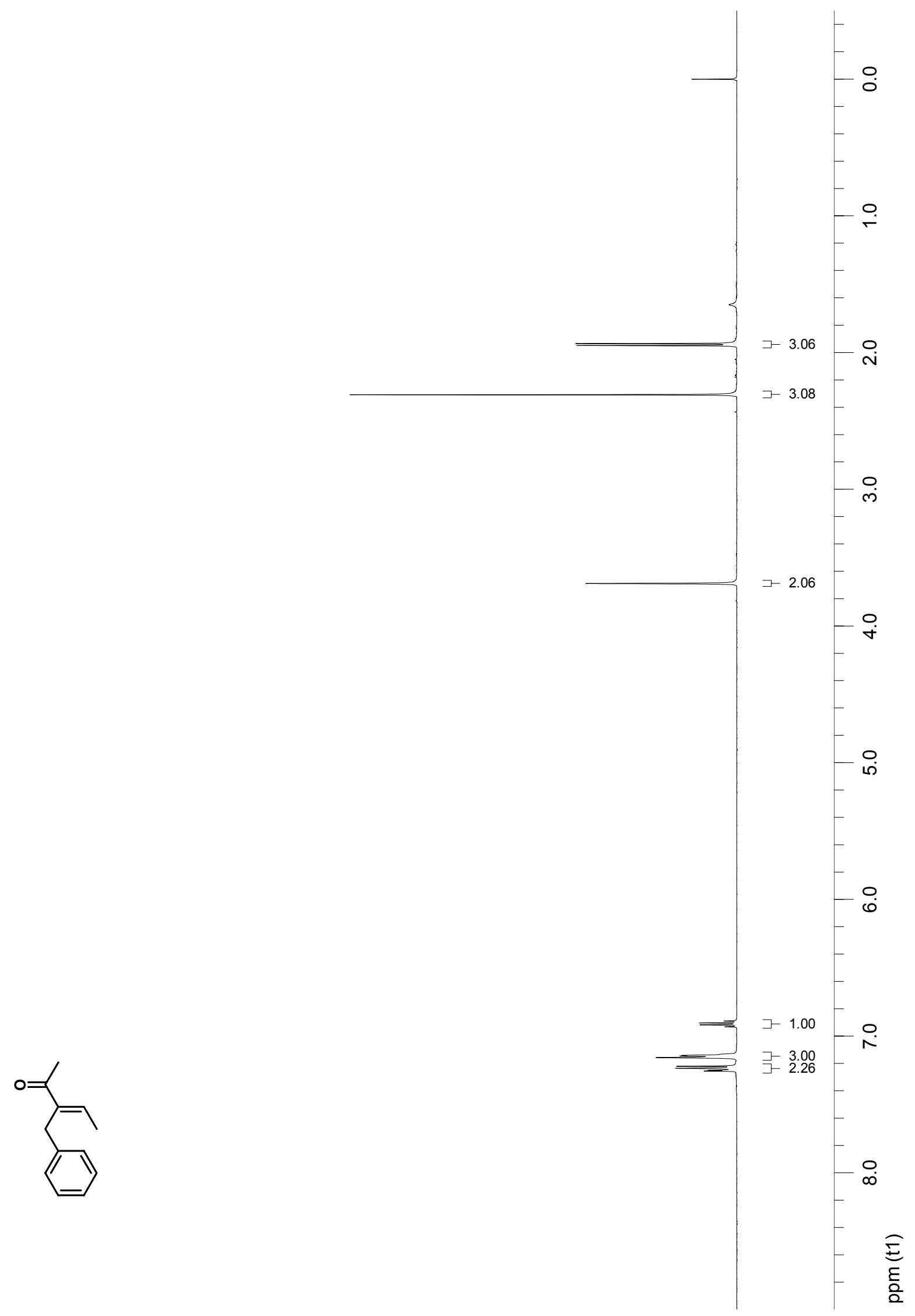


Ndungu, Larson, and Sarpong, Supporting Information 27

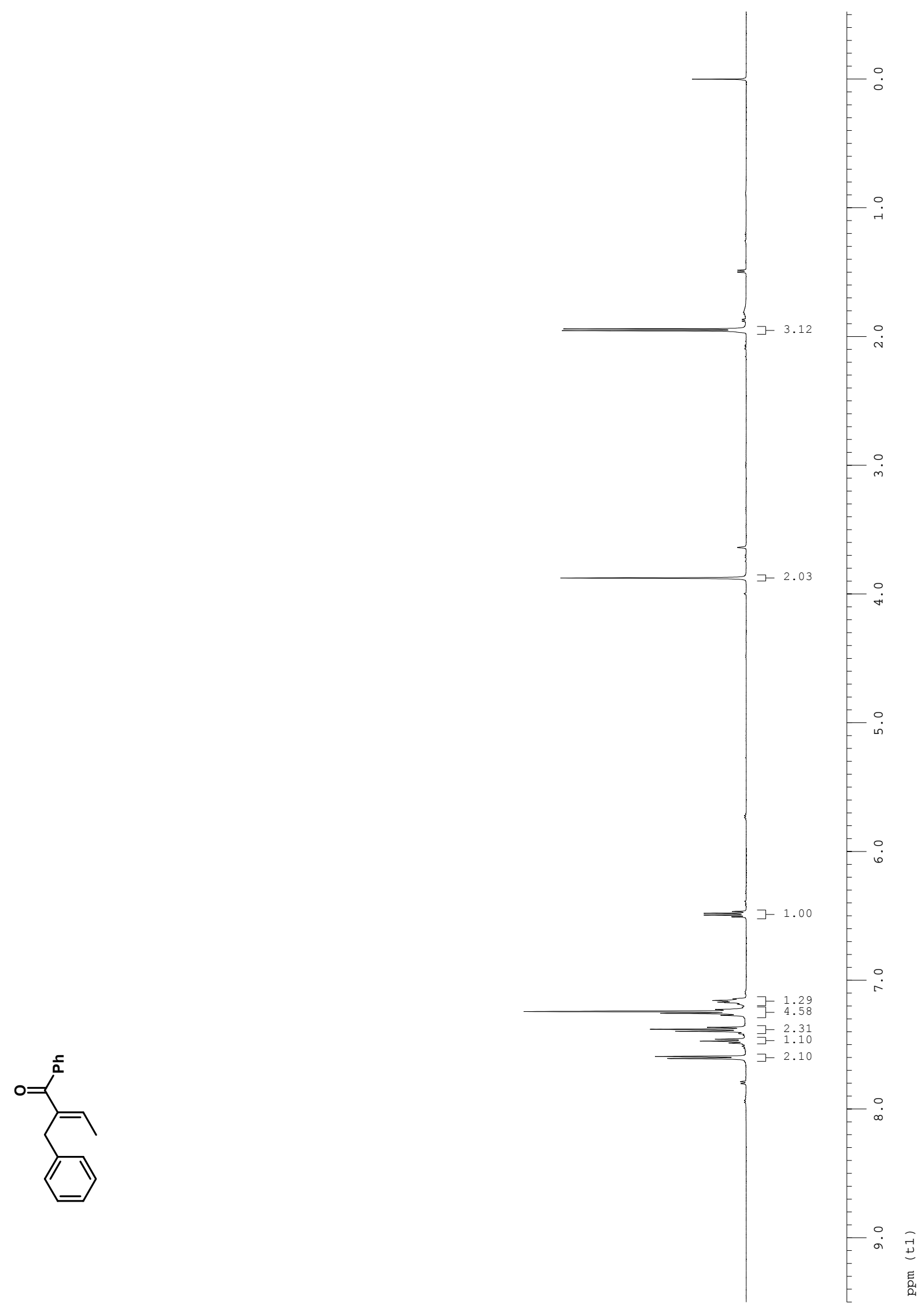


Ndungu, Larson, and Sarpong, Supporting Information 28

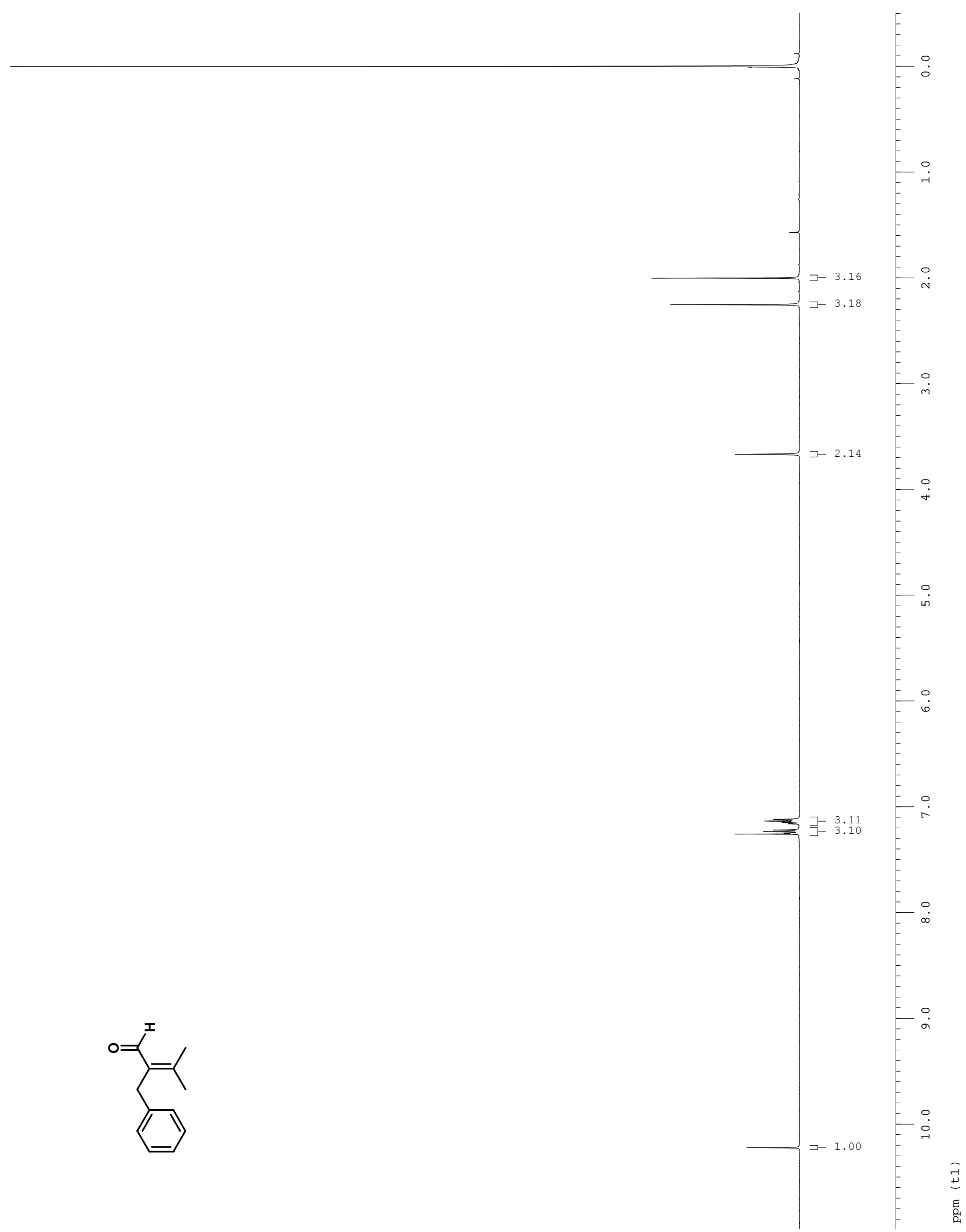


Ndungu, Larson, and Sarpong, Supporting Information 29

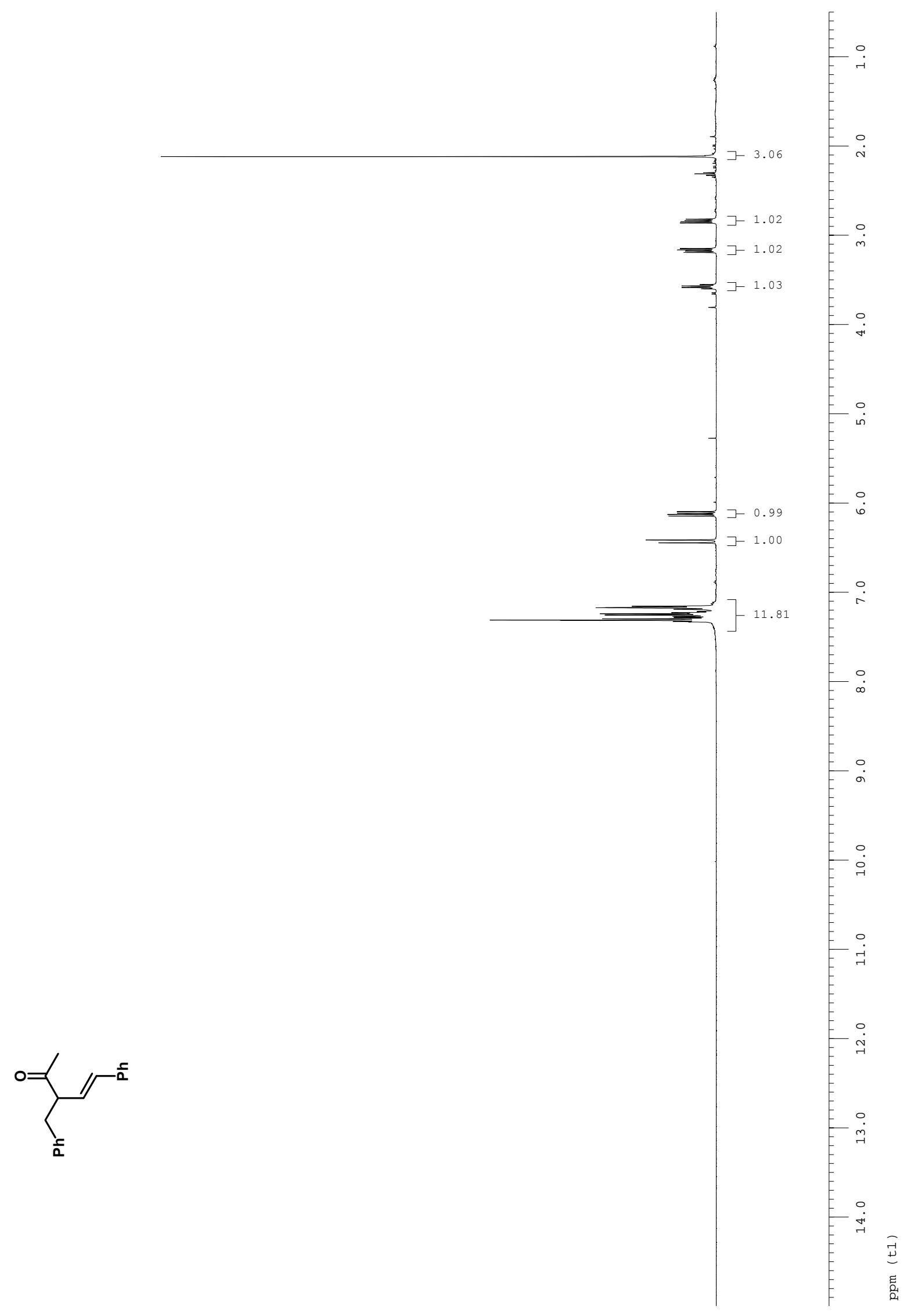


Ndungu, Larson, and Sarpong, Supporting Information 30

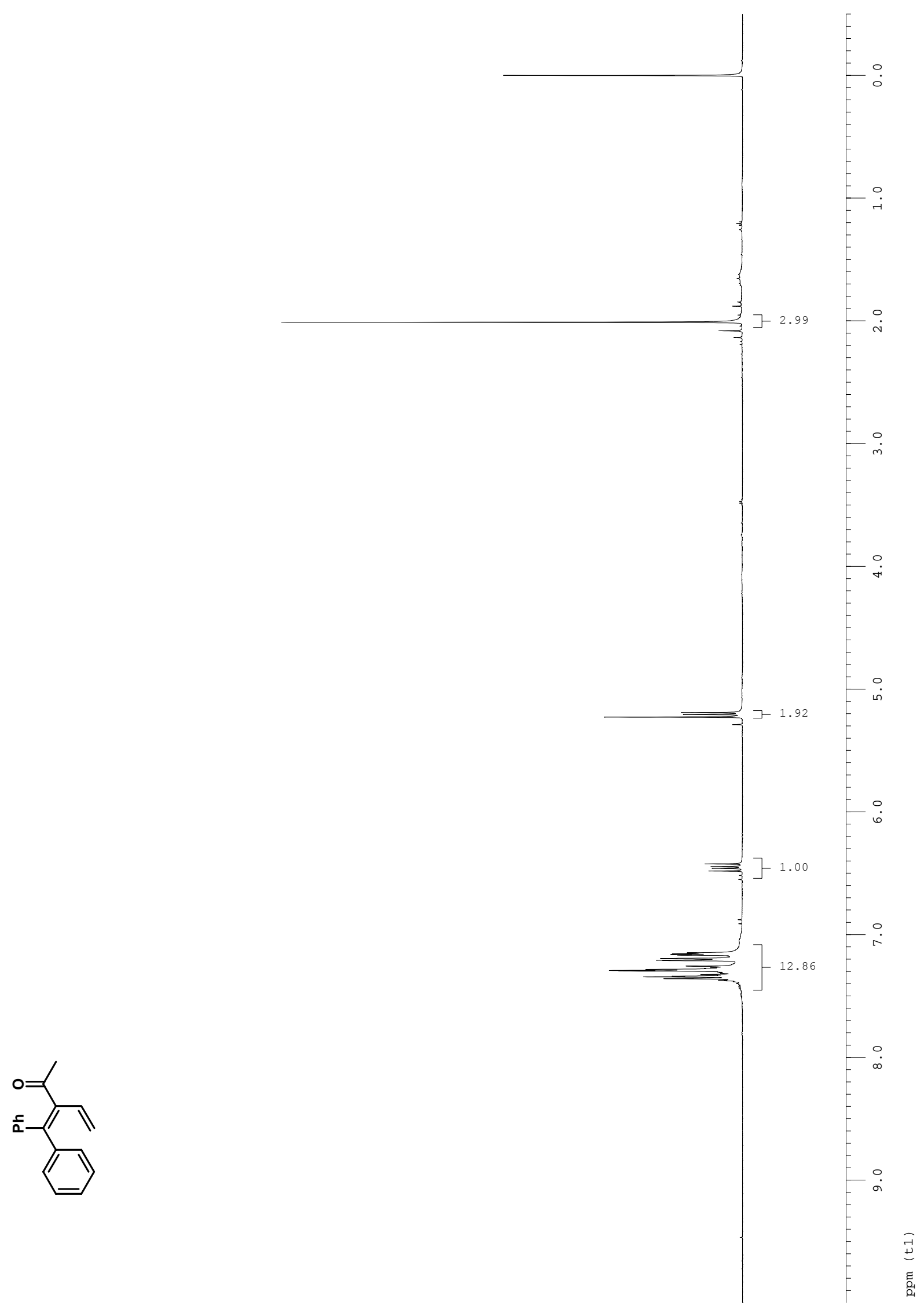


Ndungu, Larson, and Sarpong, Supporting Information 31

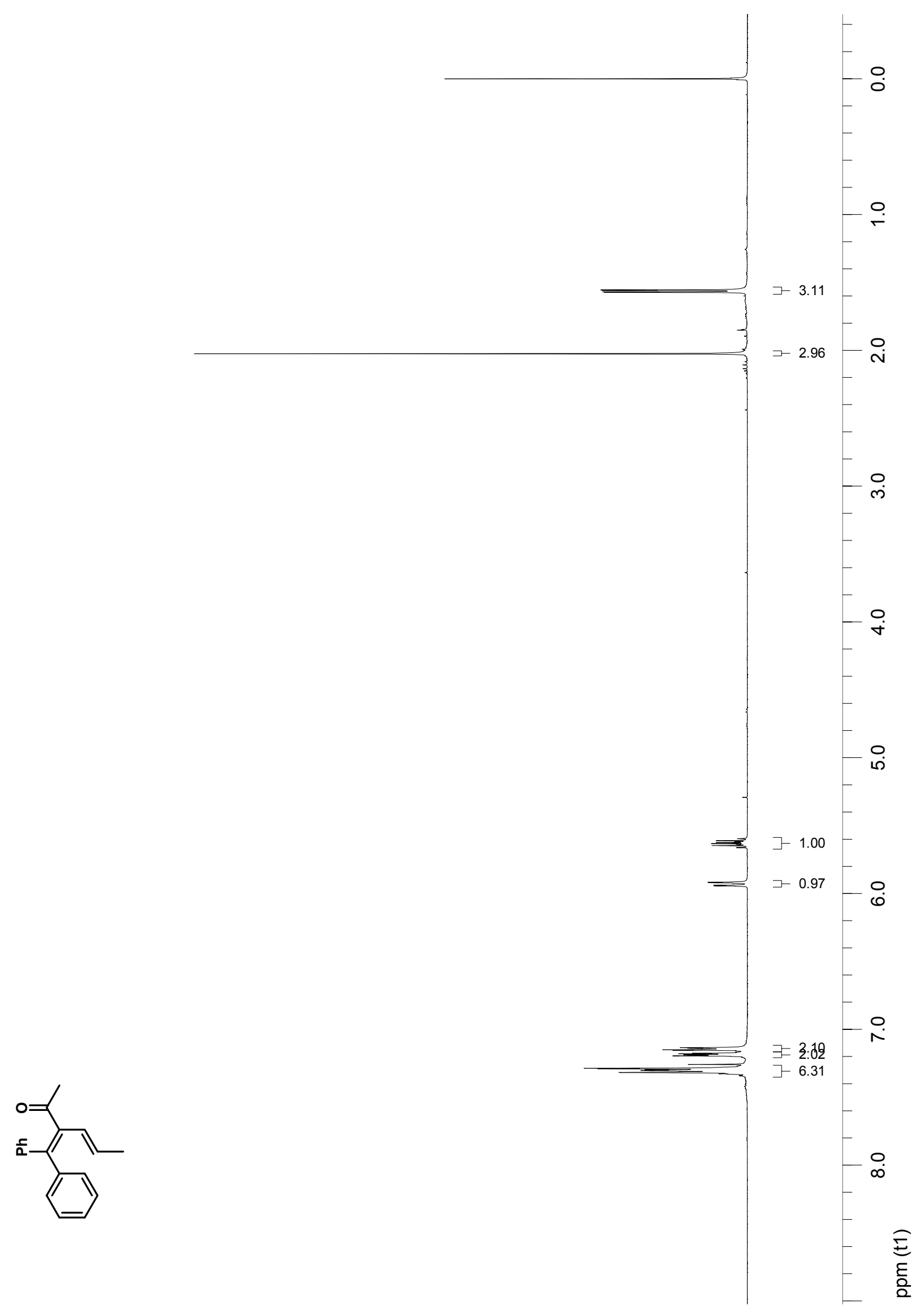


Ndungu, Larson, and Sarpong, Supporting Information 32

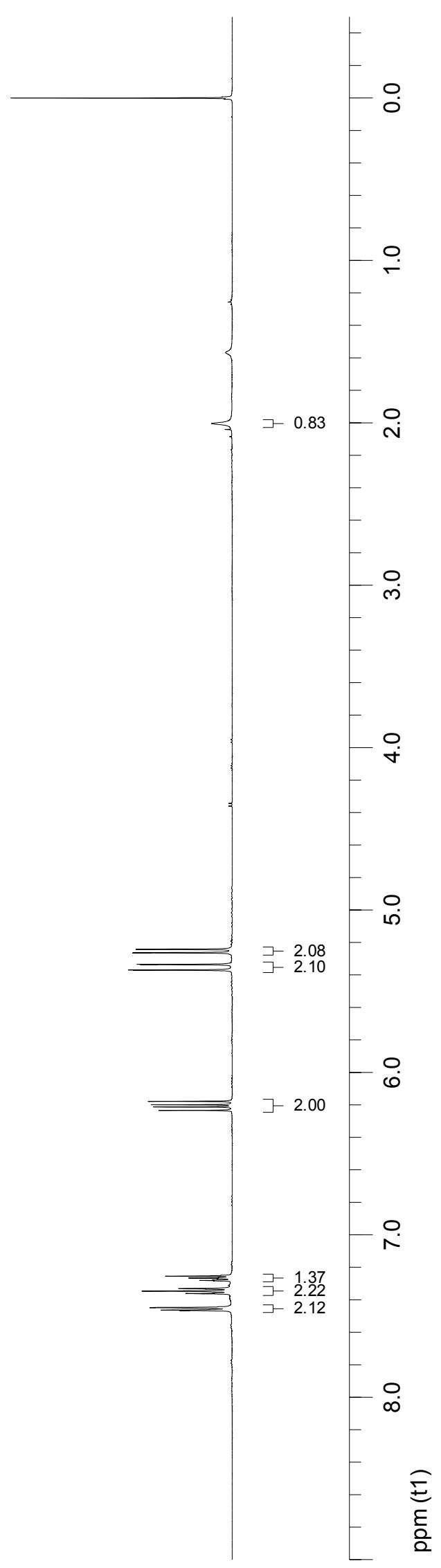


Ndungu, Larson, and Sarpong, Supporting Information 33

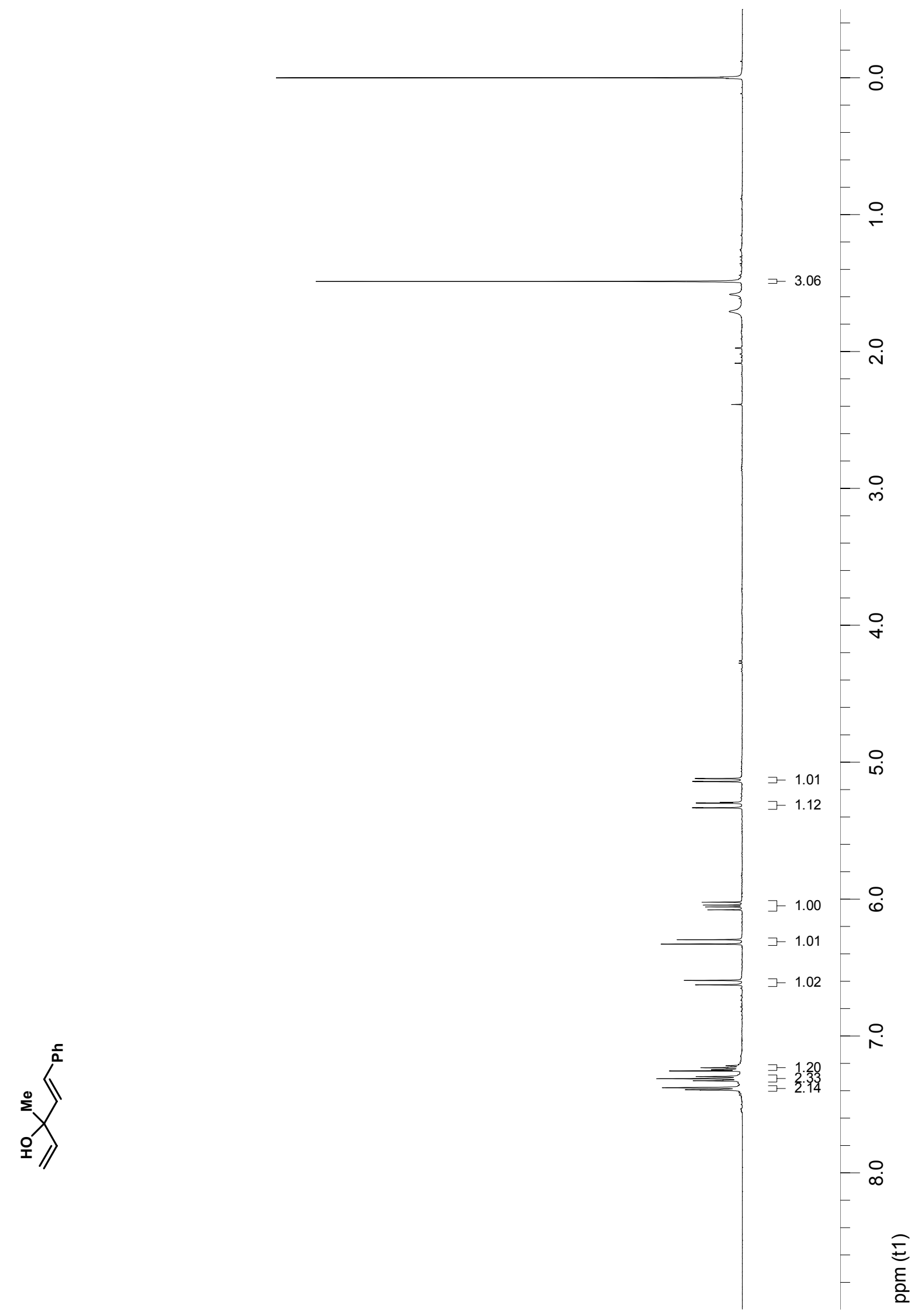


Ndungu, Larson, and Sarpong, Supporting Information 34

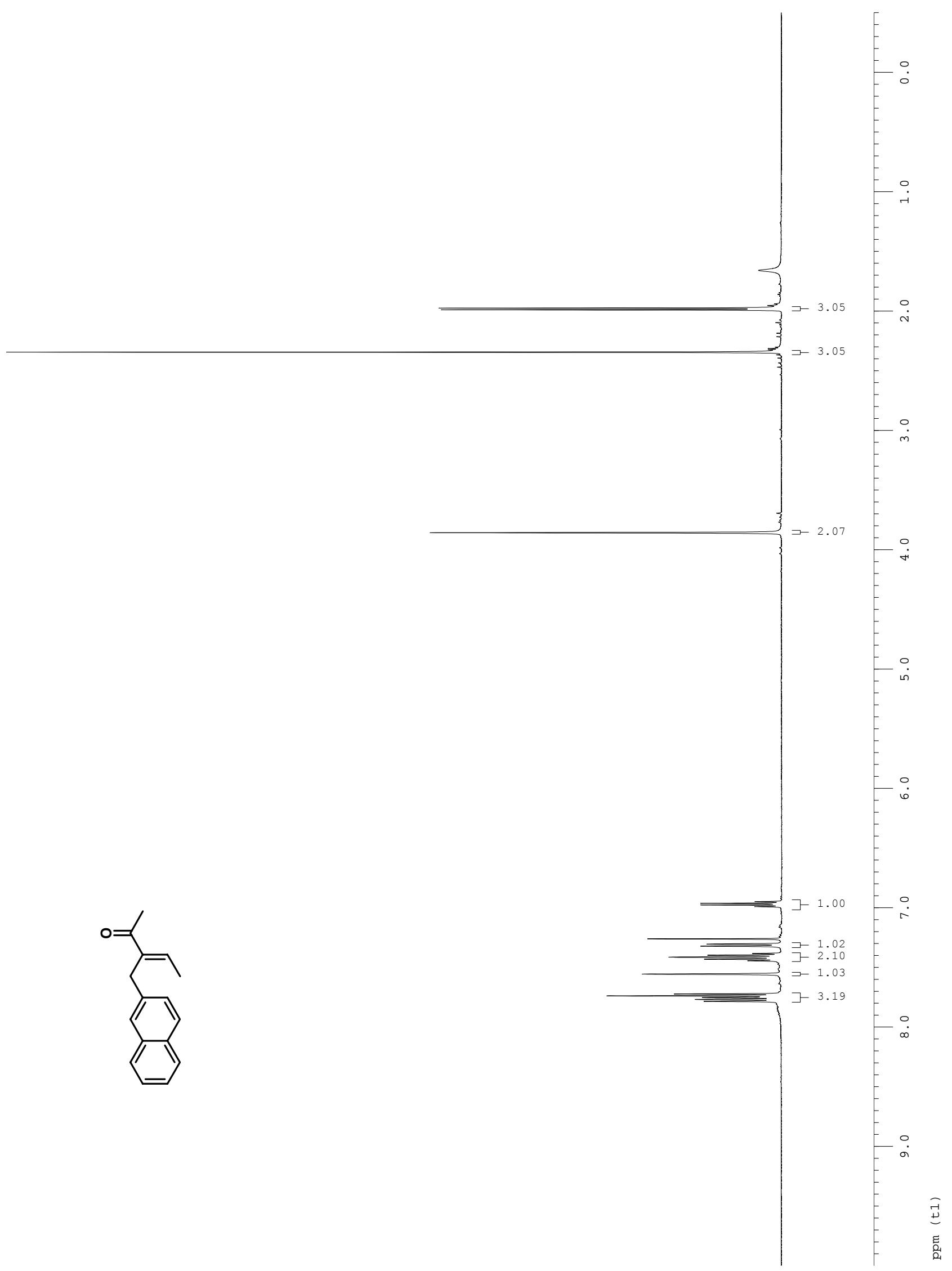


Ndungu, Larson, and Sarpong, Supporting Information 35

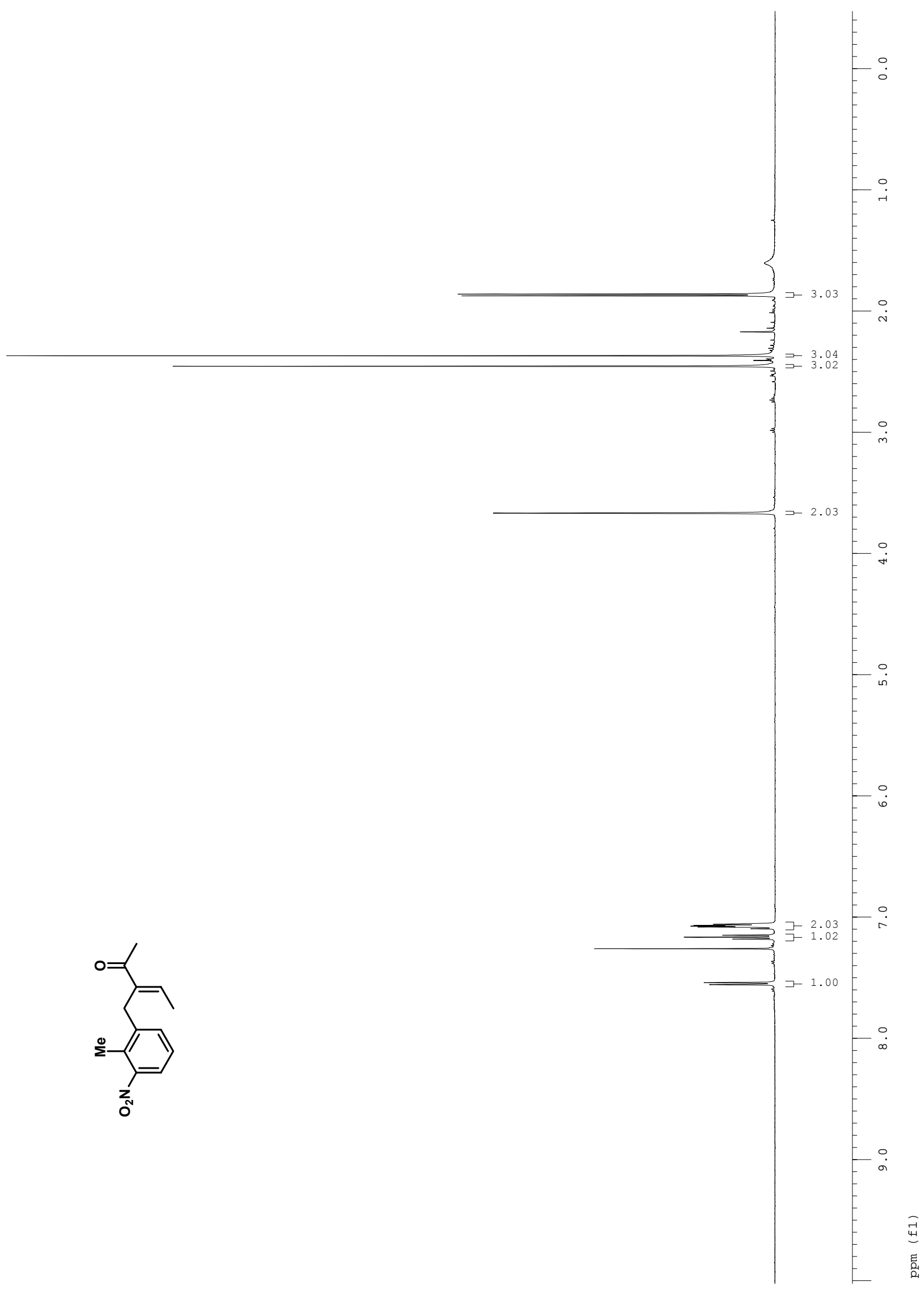


Ndungu, Larson, and Sarpong, Supporting Information 36

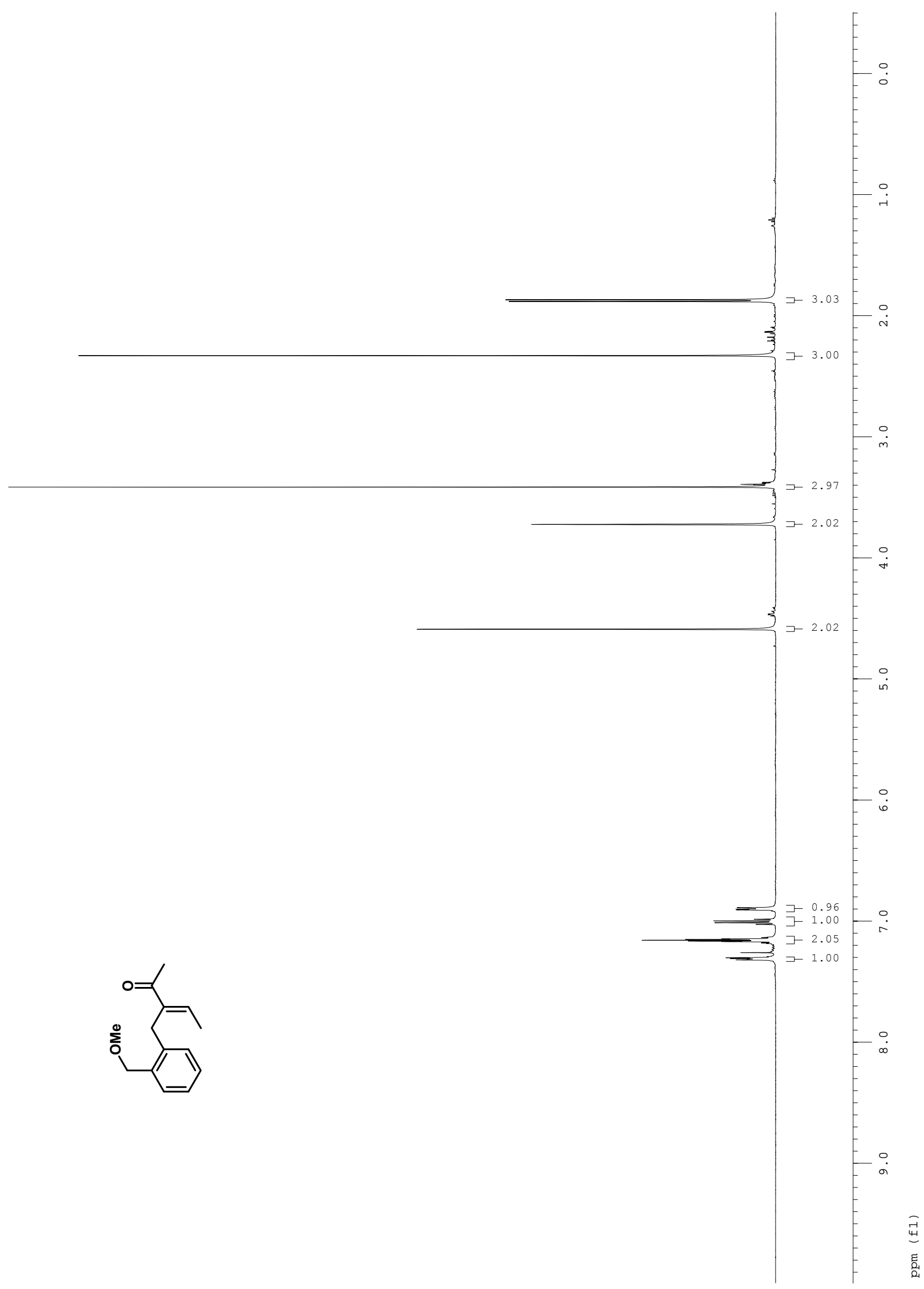


Ndungu, Larson, and Sarpong, Supporting Information 37

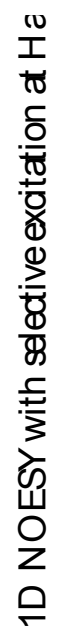

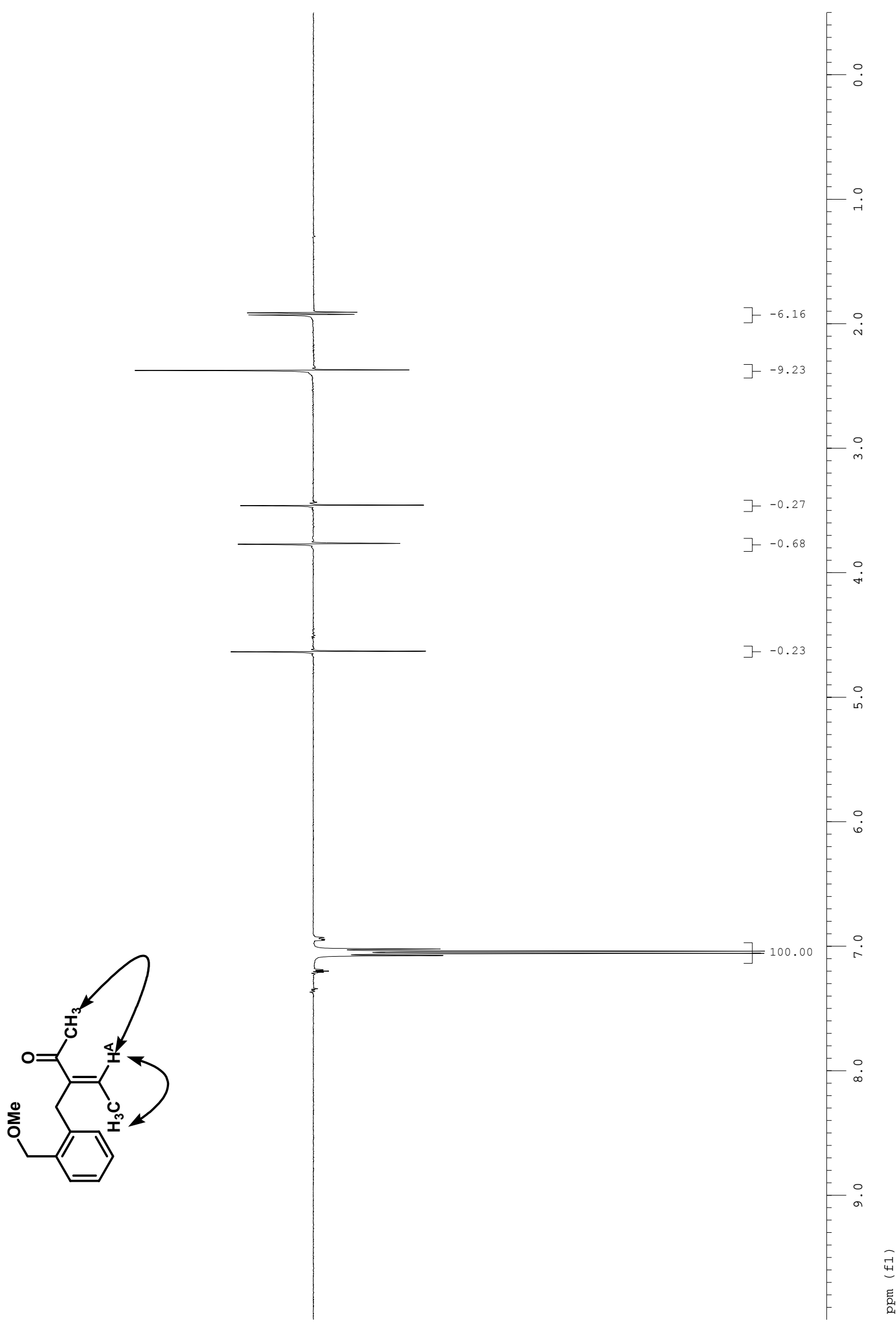


Ndungu, Larson, and Sarpong, Supporting Information 38

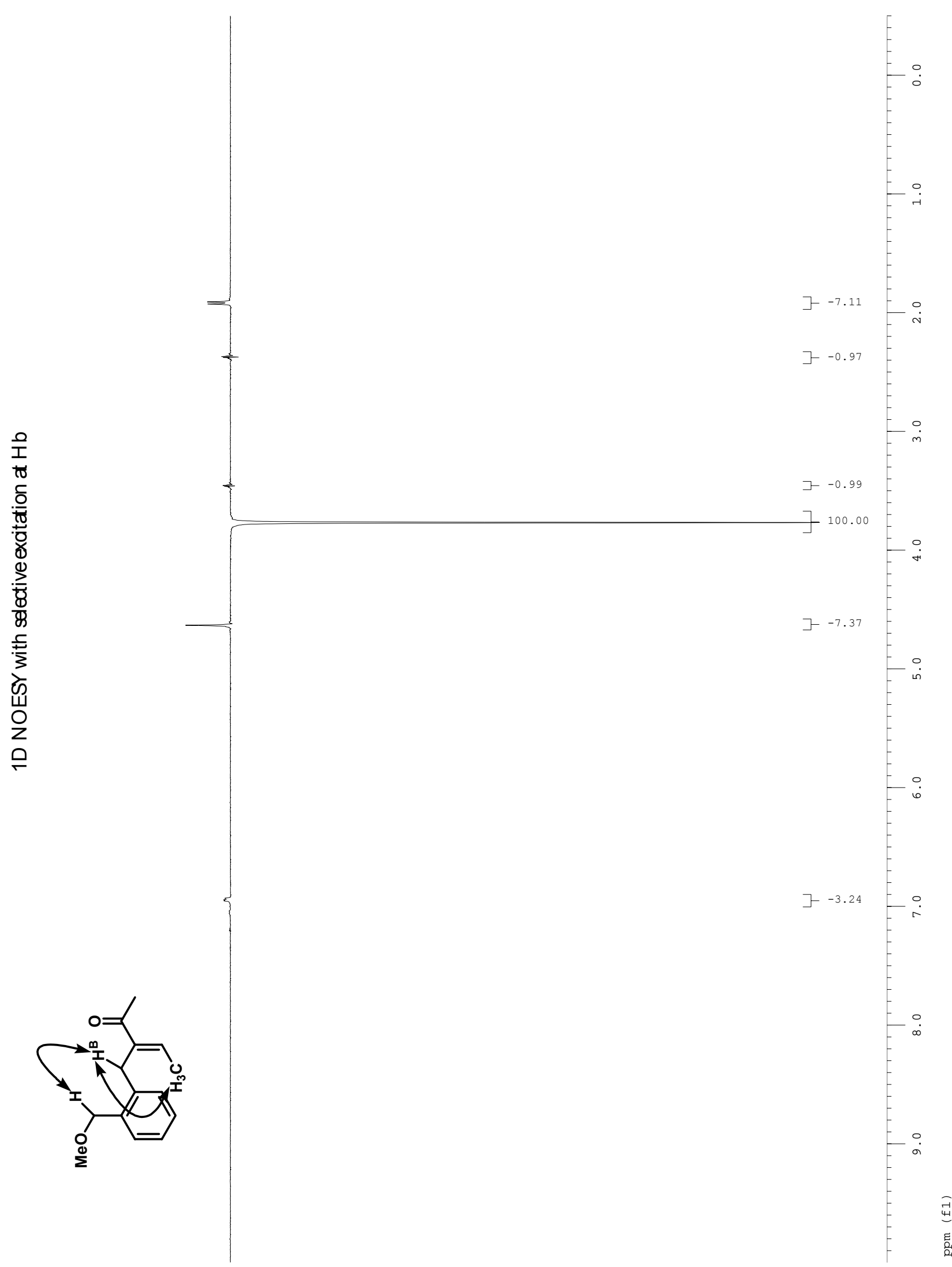


Ndungu, Larson, and Sarpong, Supporting Information 39

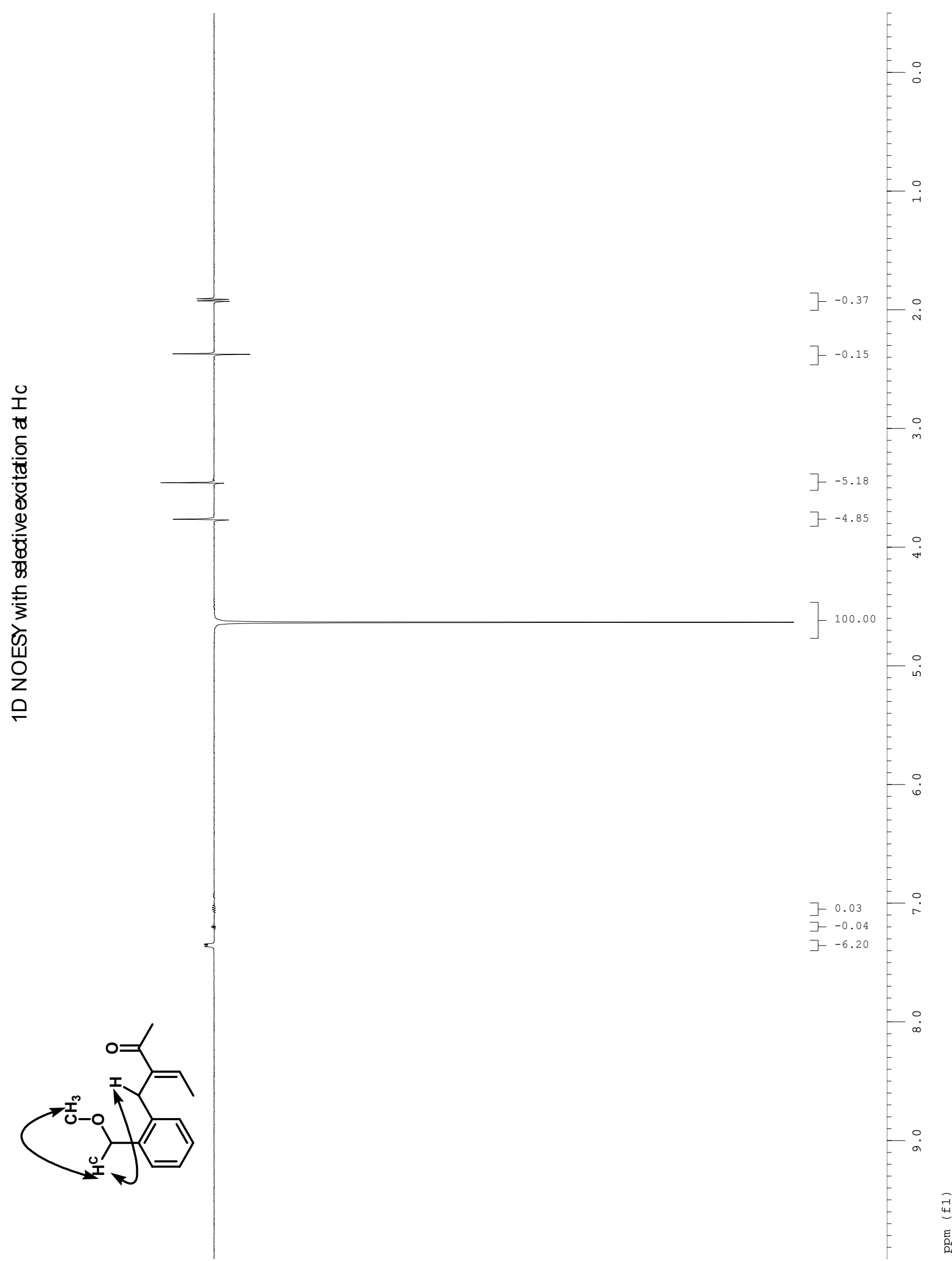


Ndungu, Larson, and Sarpong, Supporting Information 40

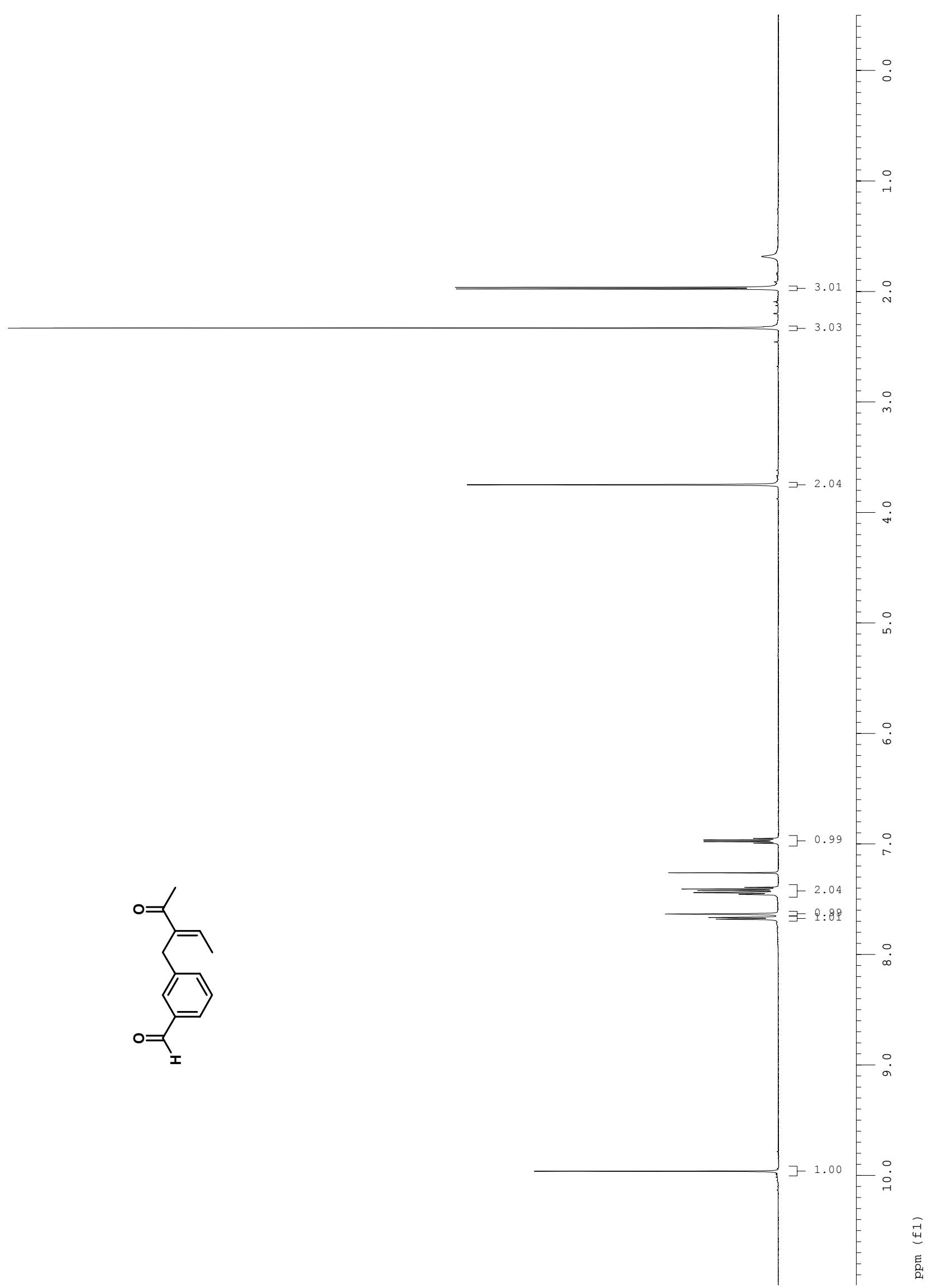


Ndungu, Larson, and Sarpong, Supporting Information 41

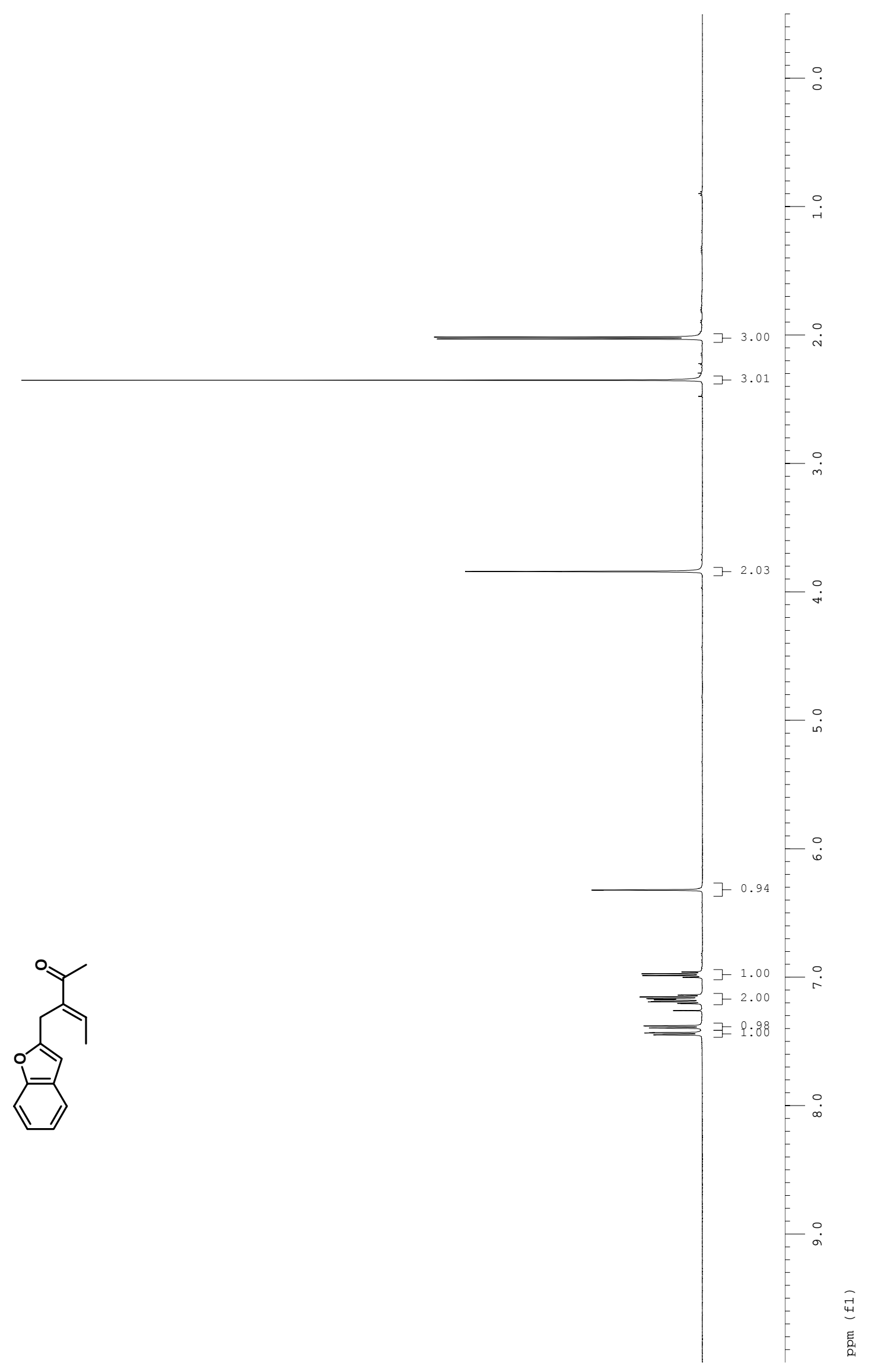


Ndungu, Larson, and Sarpong, Supporting Information 42

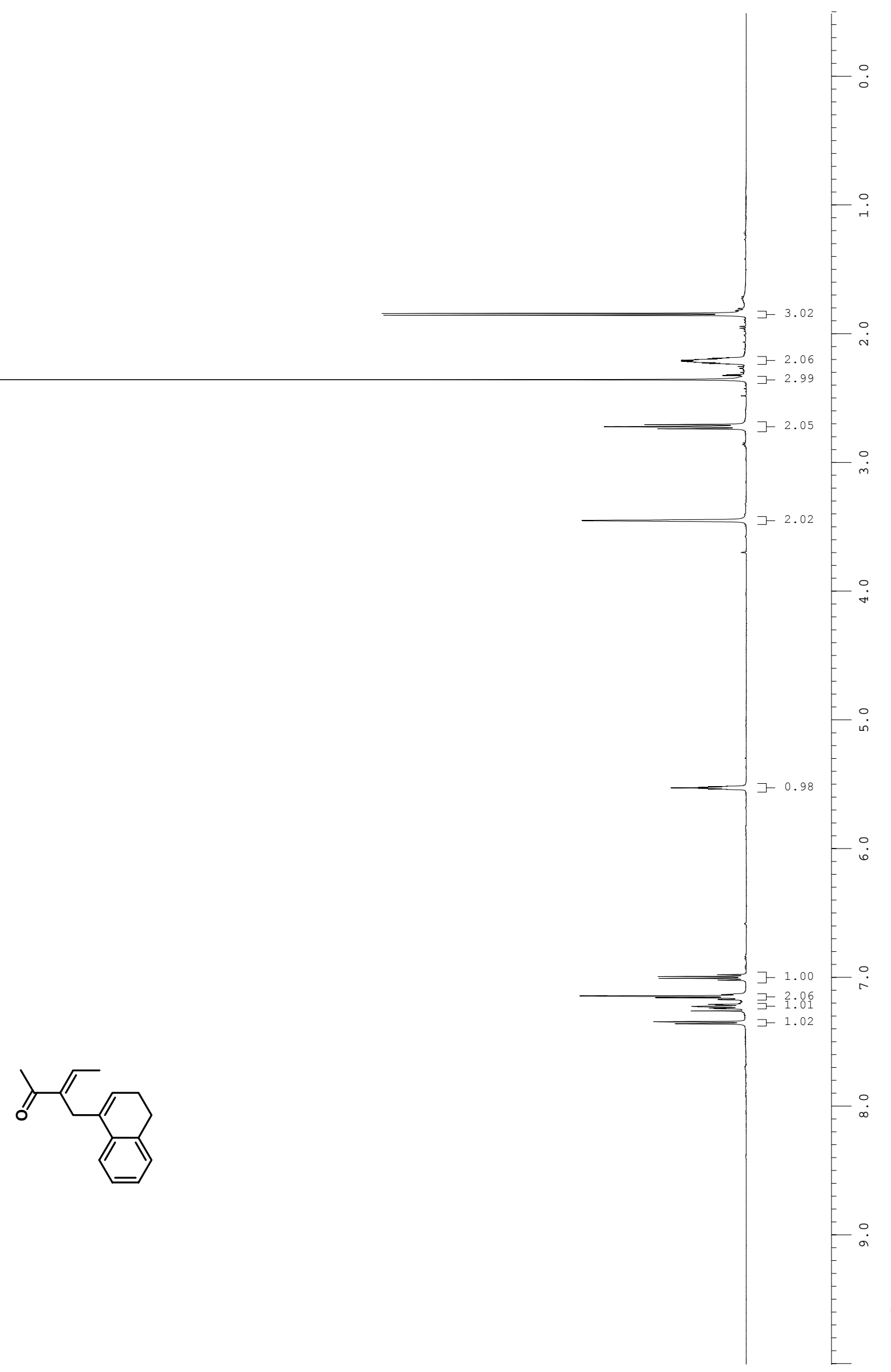


Ndungu, Larson, and Sarpong, Supporting Information 43

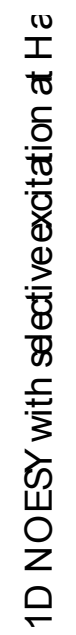

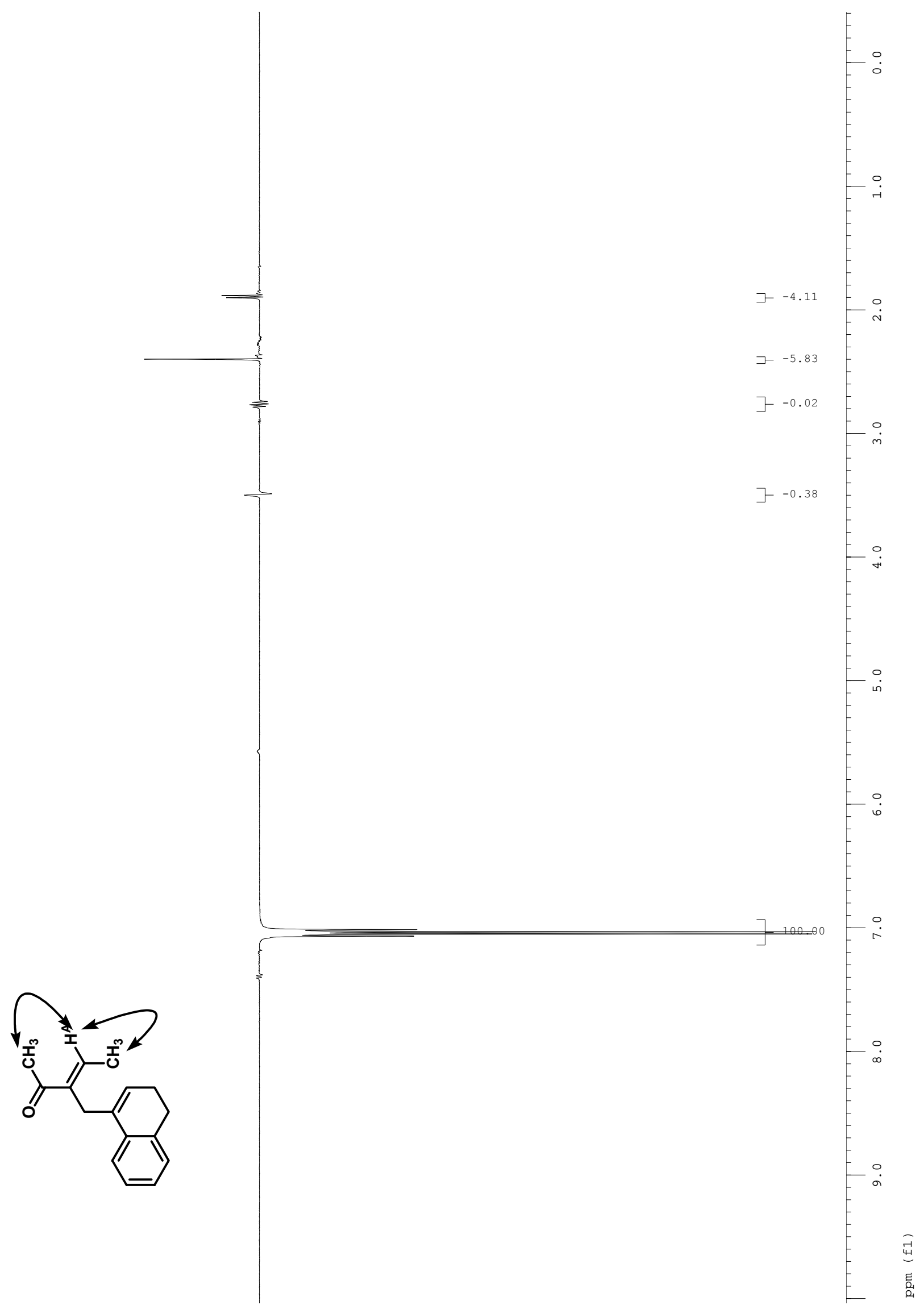


Ndungu, Larson, and Sarpong, Supporting Information 44

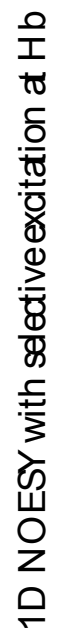

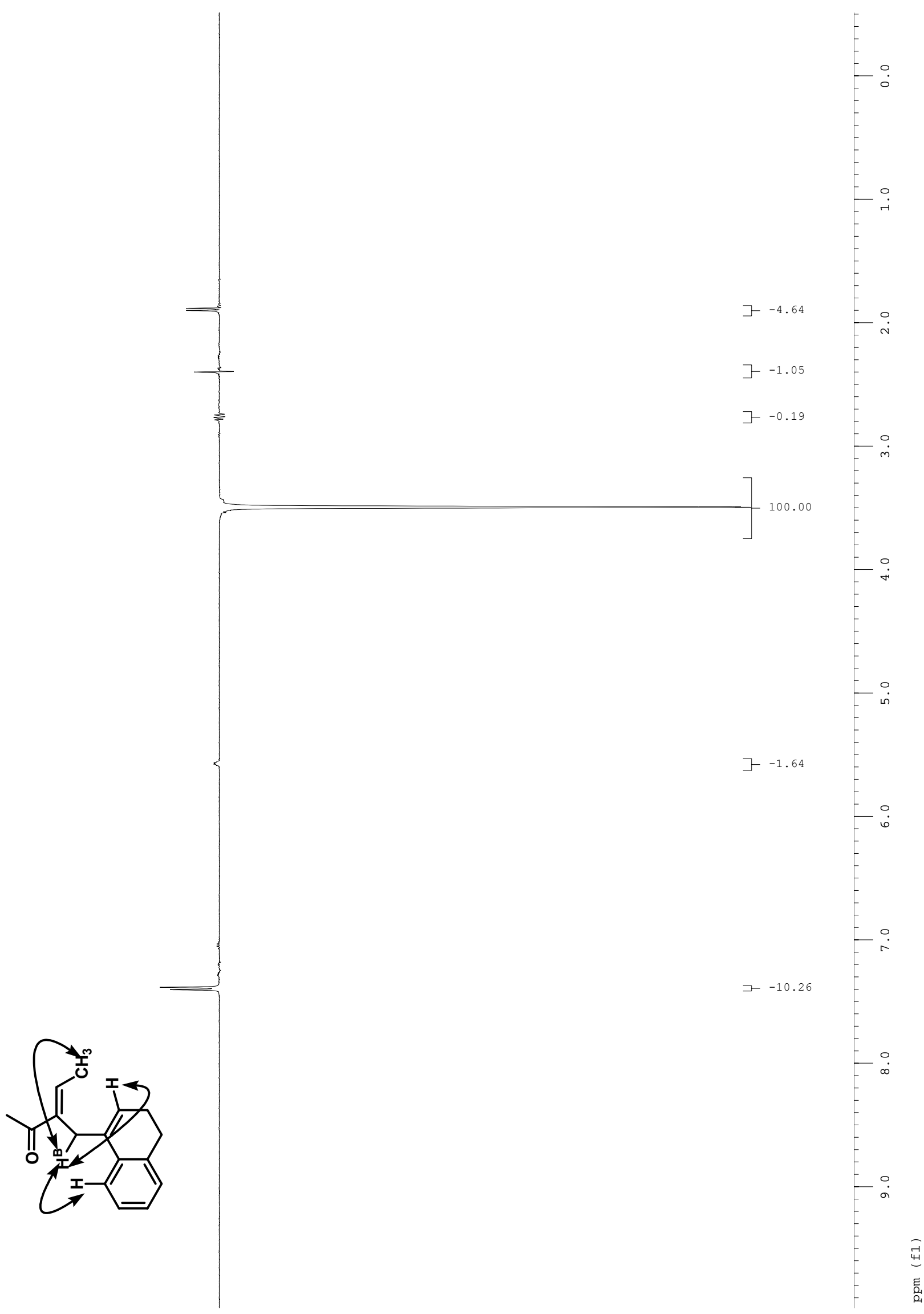


Ndungu, Larson, and Sarpong, Supporting Information 45

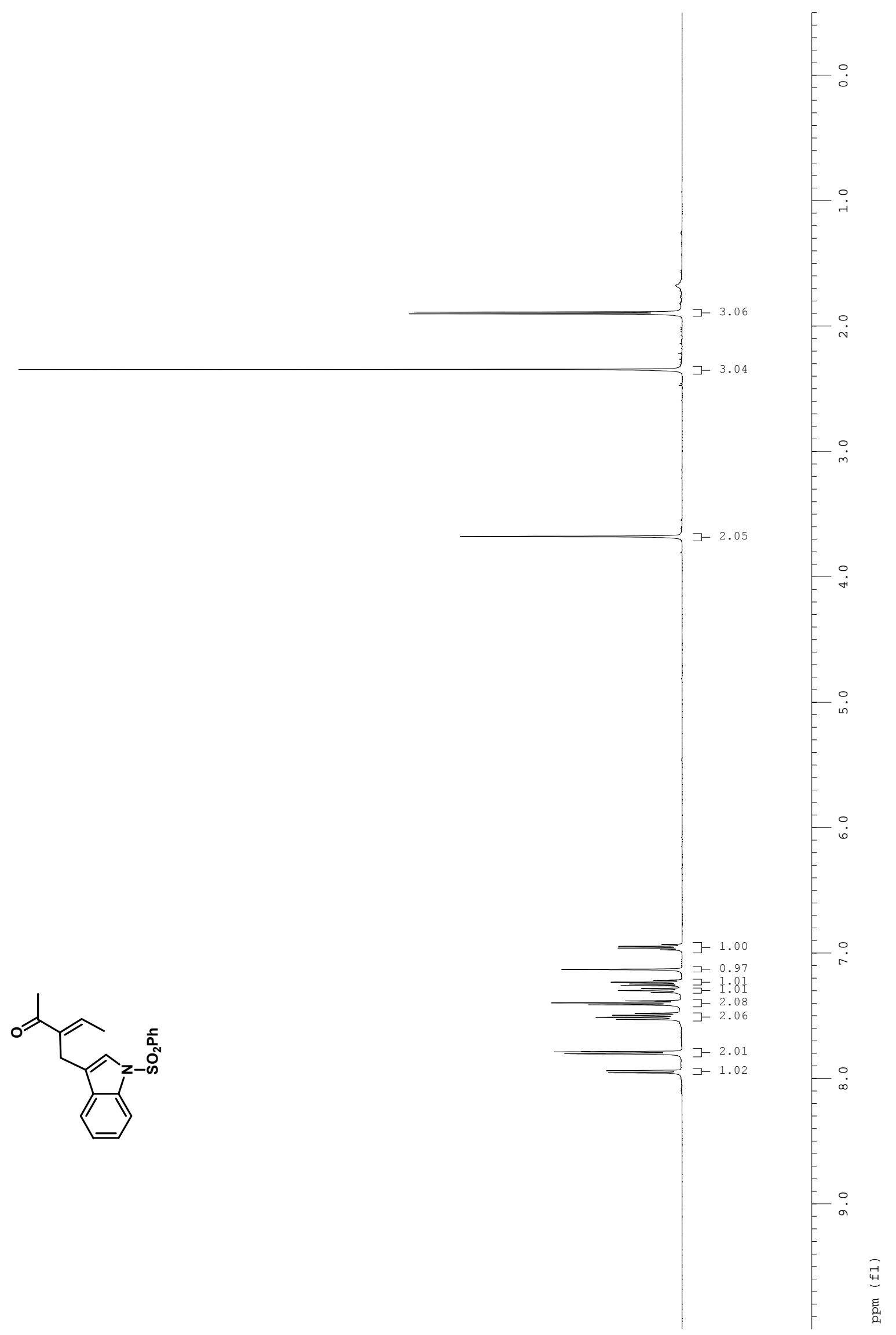


Ndungu, Larson, and Sarpong, Supporting Information 46

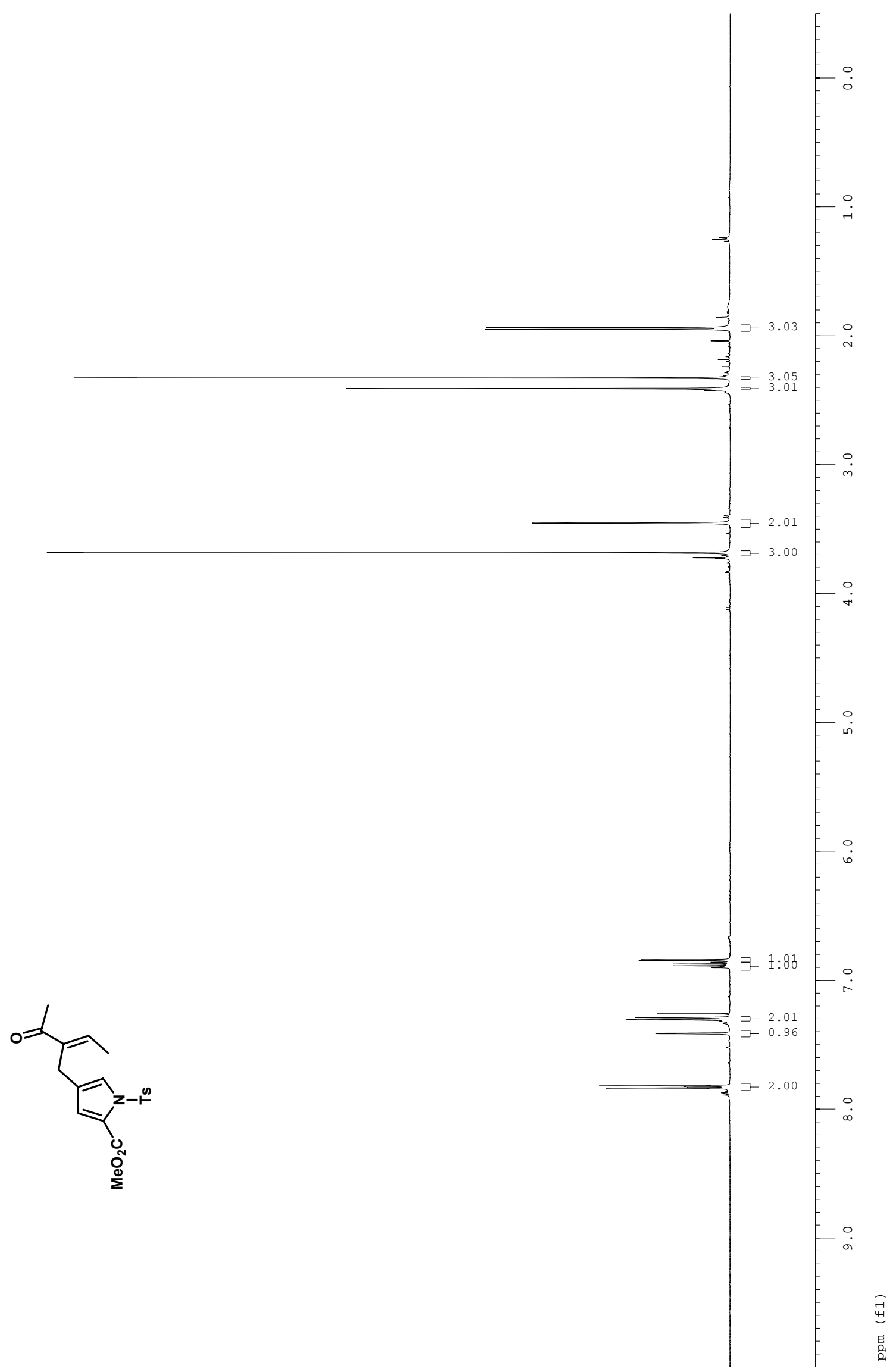


Ndungu, Larson, and Sarpong, Supporting Information 47

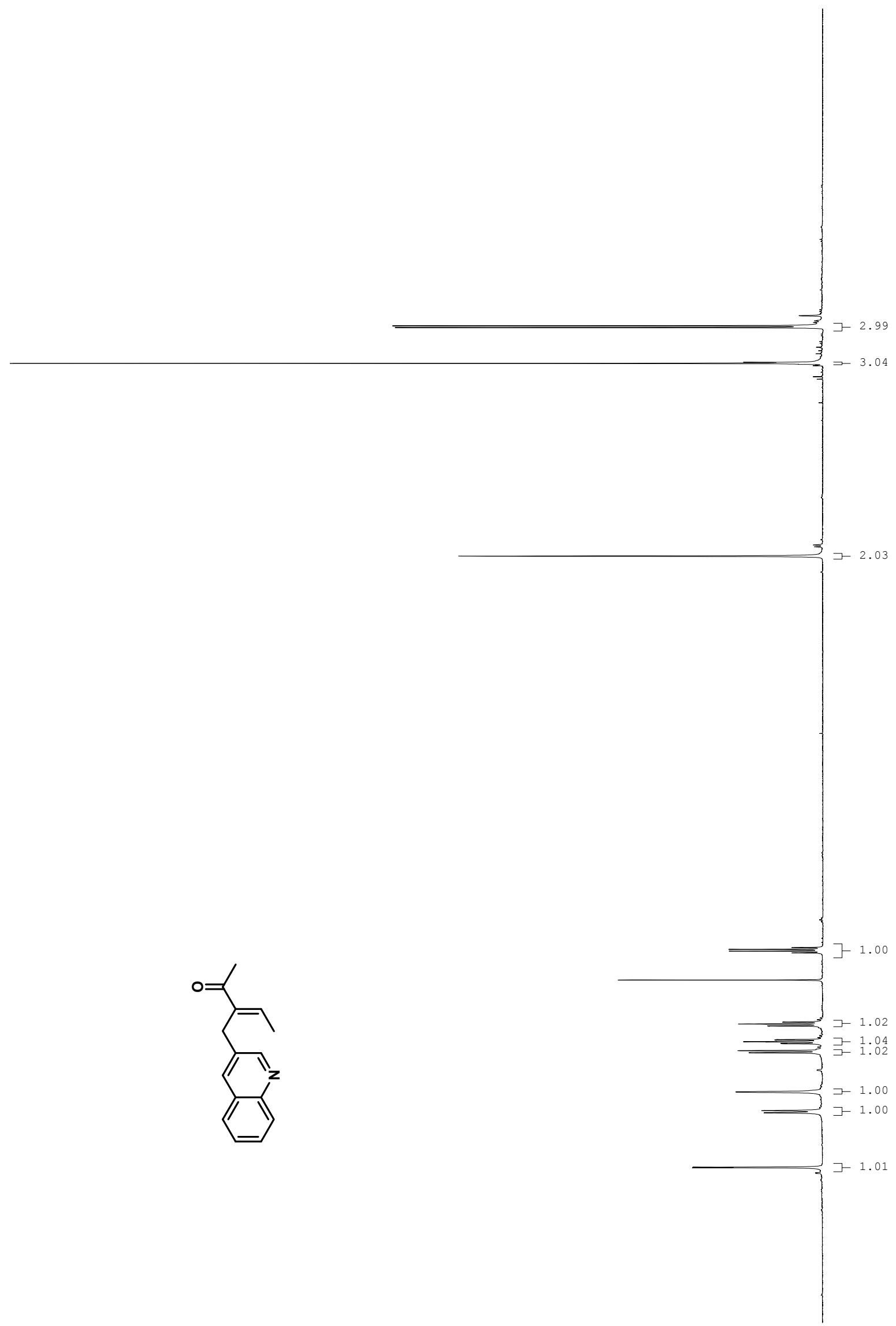


Ndungu, Larson, and Sarpong, Supporting Information 48

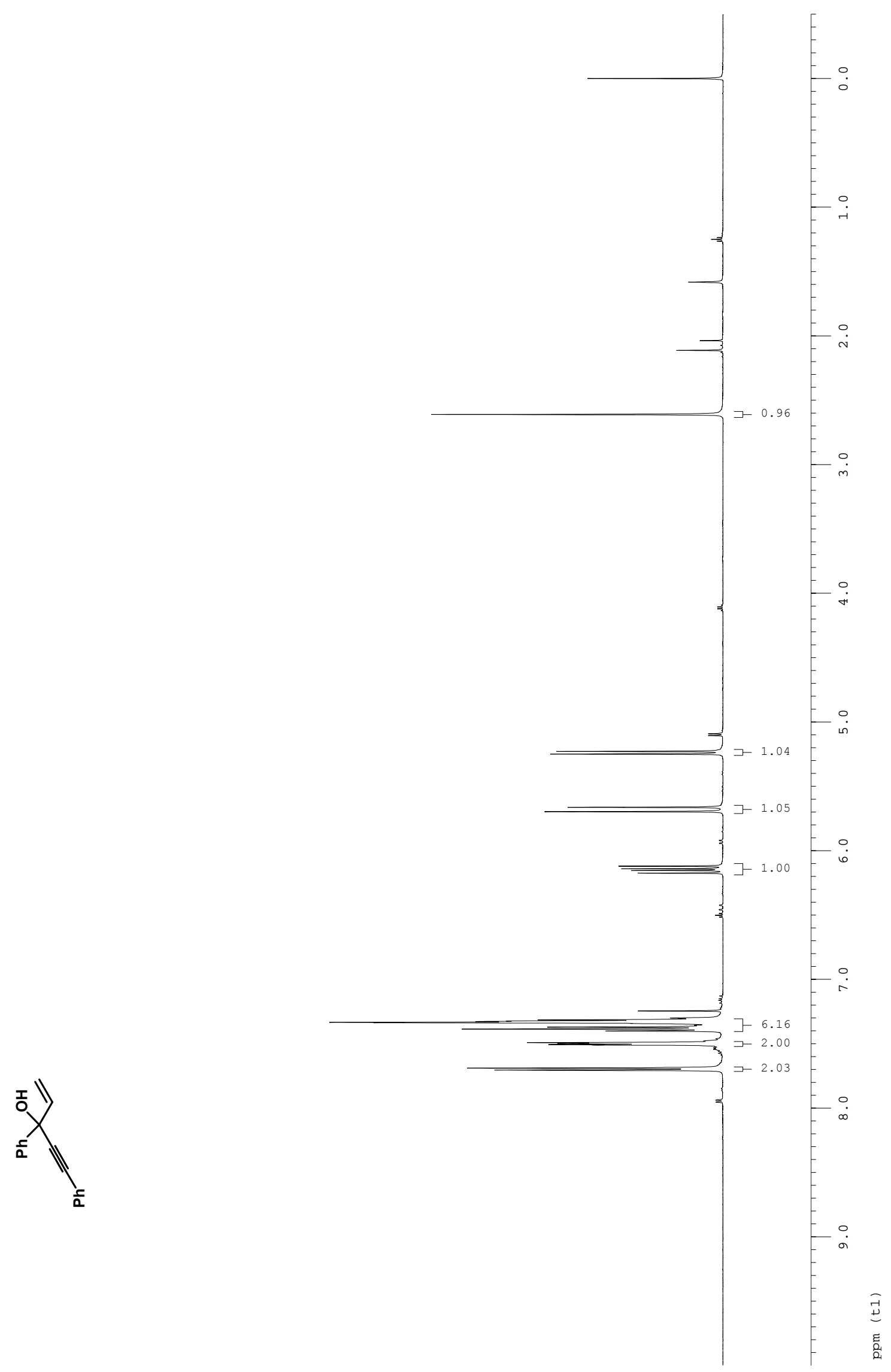


Ndungu, Larson, and Sarpong, Supporting Information 49

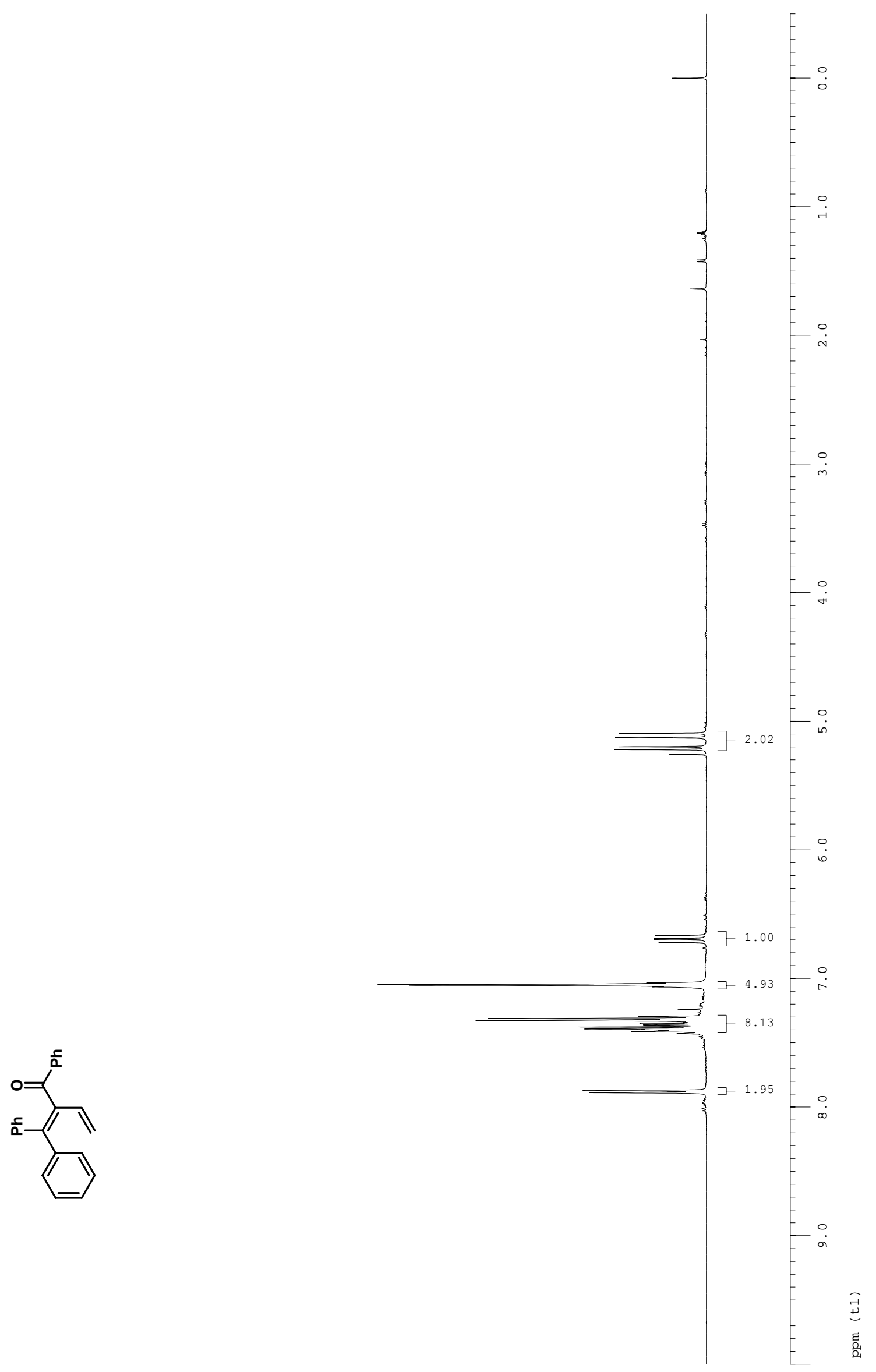


Ndungu, Larson, and Sarpong, Supporting Information 50

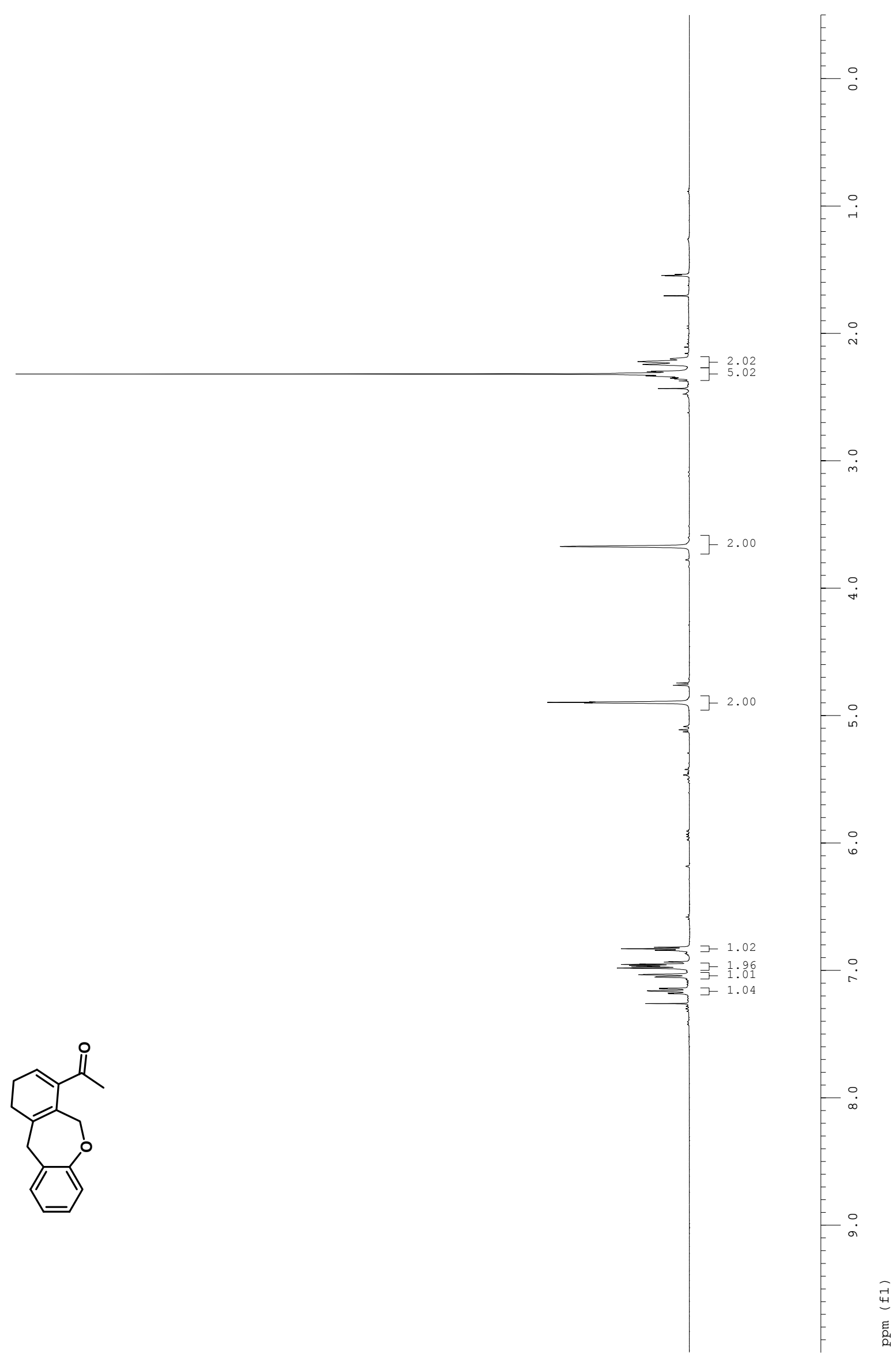

